\title{
Wakatobi Islands: Archaeological, Historical, and Maritime Tradition Perspectives \\ Kepulauan Wakatobi: Perspektif Arkeologi, Sejarah, dan Tradisi Maritim
}

\author{
Syahruddin Mansyur ${ }^{1}$, Nani Somba ${ }^{1}$, \\ Rustam Awat ${ }^{2}$, La Ode Ali Ahmadi ${ }^{3}$, \\ Hasliana $^{1}$ \\ ${ }^{1}$ Regional Agency for Archaeological Research in \\ South Sulawesi Province \\ ${ }^{2}$ Dayanu Ikhsanuddin University \\ ${ }^{1}$ Southeast Sulawesi Tourism Office \\ Correspondence: \\ syahruddin.mansyur@kemdikbud.go.id
}

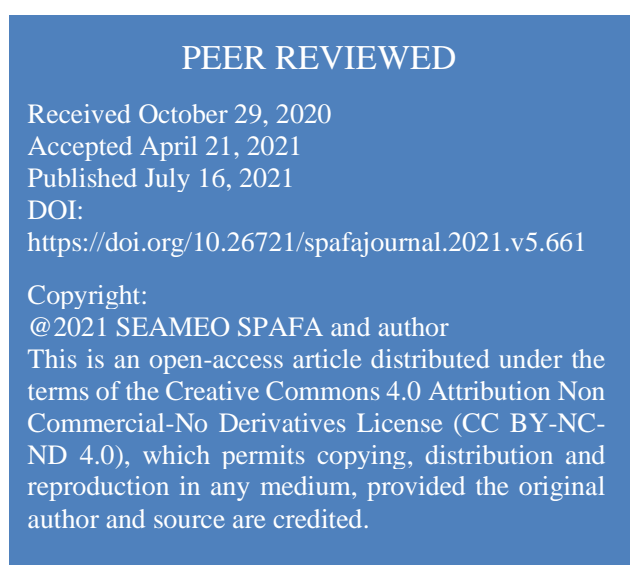

\begin{abstract}
Wakatobi Islands, which are located east of Buton Island, were part of the territory of the Buton Kingdom in the past. Wakatobi Islands cover an area known as a shipping route connecting the eastern and western regions of the Nusantara archipelago. The historical journey of the people of Wakatobi Islands led them to have a strong maritime tradition in Nusantara. This paper discusses issues related to the initial overview of the Wakatobi Islands from the perspectives of archaeology, history, and maritime traditions. The methods used include survey and observation as well as literature study and interviews. The results obtained provide a regional profile of the Wakatobi Islands, which shows that archaeological remains and the traditional fortresses spread in the area are residential sites that reflect the archaeological character of the islands. The identification that we have conducted on the ceramics shows that they date from at least the $15^{\text {th }}$ century, with ceramics from the Qing dynasty ( $17^{\text {th }}$ to $19^{\text {th }}$ centuries) being the most dominant. The historical perspective also gives an understanding that the maritime tradition of the Wakatobi people has strong historical roots in the formation of communities in this region. Likewise, the history and maritime traditions of the Wakatobi people are correlated with archaeological remains which are the traces of immigrants who developed the communities of the Wakatobi Islands.
\end{abstract}

Kepulauan Wakatobi yang terletak di sebelah timur Pulau Buton merupakan bagian dari wilayah kekuasaan Kesultanan Buton di masa lampau. Wilayah kepulauan ini adalah kawasan yang dikenal sebagai jalur pelayaran penghubung wilayah timur dan barat Nusantara. Perjalanan sejarah masyarakat Kepulauan Wakatobi sekaligus mengantarkan wilayah ini memiliki tradisi kemaritiman yang kuat di nusantara. Tulisan ini membahas permasalahan terkait tinjauan awal Kepulauan Wakatobi dipandang dari perspektif arkeologi, sejarah dan tradisi kemaritiman. Metode yang digunakan adalah metode survei atau observasi dan juga studi pustaka dan wawancara. Hasil yang diperoleh memberi pemahaman tentang profil wilayah Kepulauan Wakatobi bahwa tinggalan arkeologi dan persebaran benteng tradisional merupakan situs hunian yang merefleksikan karakter arkeologi kepulauan wilayah ini. Identifikasi awal yang kami lakukan, data keramik menunjukkan pertanggalan mulai sebelum atau pada abad ke-15, dimana keramik periode Qing abad ke-17 dan 19 adalah paling dominan. Perspektif sejarah juga memberi pemahaman bahwa tradisi kemaritiman 
masyarakat Wakatobi memiliki akar sejarah yang kuat dari terbentuknya komunitas masyarakat di wilayah ini. Demikian juga dengan sejarah dan tradisi kemaritiman masyarakat Wakatobi berkorelasi dengan tinggalan arkeologi sebagai jejak kehadiran pendatang dari luar wilayah yang membentuk masyarakat Kepulauan Wakatobi.

Keywords: traditional forts, the archaeology of islands, Wakatobi, maritime traditions | benteng tradisional, arkeologi kepulauan, Wakatobi, tradisi kemaritiman.

\section{Introduction}

An interview by the Archaeology Research Team with Mr. Rahmat La Mudia, an informant from Taipabu, Togo Binongko, Wakatobi District, revealed an interesting expression. It is said that when someone asks the whereabouts of any Taipabu resident, it is frequently answered with "he is visiting his farm in Bonerate”, located in Selayar District of South Sulawesi. This kind of expression shows us that the residents of Binongko Island (and Wakatobi in general) see an overseas journey as normal and habitual. However, this "farm visiting" activity needs to be performed by crossing the sea with safety at stake. For Wakatobians, "visiting farms" means to seek out a livelihood by opening new farms overseas at certain times and coming home after harvest. It can be seen that the expression reflects the Wakatobi people's strong maritime traditions.

Wakatobi is the acronym that stands for the four main islands of Wakatobi Islands, namely Wangiwangi, Kaledupa, Tomia and Binongko, which are located in the southeast of mainland Sulawesi. The Wakatobi people are known for their maritime traditions and vast diasporas and their historical background spans over hundreds of years. The people who inhabit the Wakatobi Islands are the Butonese, Bajau, and several ethnic immigrants from Malay, Javanese, Bugis, and Bajau. The Wakatobi know the Wolio language (the native language of the Buton Kingdom), the Cia-Cia language (south Buton) the Bajau language, and the Mbeda-beda language as the native language of the Binongko people. Archaeological evidence shows us the traces of Wakatobian communities with their forms and models of adaptation to the environment. One line of evidence that reflects this adaptation is the stone-fortified settlements which were constructed on each of the larger Wakatobi Islands, specifically Wangi-wangi, Kaledupa (Rosmawati 2018; Somba 2020), Kapota, Tomia, and Binongko.

The roles and functions of these fortifications within Wakatobi have also been investigated using archaeological research. This research shows us the variability of findings, such as old mosques, old tombs, cannon, and ceramics fragments at Liya Fort (Wangi-wangi) and Kaledupa Fort (Ollo) on Kaledupa Island. The archaeological wealth within these two fort complexes shows their roles as governmental activity-centers. Both forts also have roles and functions connected to the Buton Kingdom's Defence System. In the context of the layered defense of the Buton Kingdom, a defense system is known to maintain sovereignty, namely east and west. This system known as the Barata System had Kaledupa Fort assigned as the easternmost defense of the Buton Kingdom, while Tiworo and Muna Forts served as the western defense of the Buton Kingdom. This is also reflected in the royal structure, namely the minister who guards the eastern part called Matanaeyo which means sunrise and Sukanaeyo which means sunset (Zuhdi 2010 and 2014). Another related aspect is the positioning of these forts on high ground, which shows that security was the main factor for the historical selection of their settlement locations. Wakatobi was often attacked by pirates known as Sanggila (Rosmawati 2018; Somba 2020). Besides Liya Fort, another fort in Wangi-wangi is 
Mandati Tonga, which contains the settlement remains of old tombs, and earthenware and ceramic fragments along with kitchen trash in the form of clamshell middens. These findings bring us a preliminary understanding of archaeological perspectives on Wakatobi Islands.

In the maritime context, the geographical position and territorial geology of the islands were the main thrusts for the emergence of the strong maritime tradition of the Wakatobi people.

Geographically, Wakatobi was located on a shipping lane which connected the east and west regions of the Indonesian Archipelago as well as the Nusa Tenggara Islands to the south and Sulawesi to the north. The maritime tradition that links Wakatobi with the outside world has been known since at least the $14^{\text {th }}$ century as part of the shipping lanes called the trading zone of the Java Sea (Hall 2010; Hamid 2007). On these shipping lanes, Wakatobi Islands was a strategic point along the Makassar-Baubau-Wakatobi (Toekang Besi)-Buru-Ambon-Banda path (La Malihu 1998; Hamid 2015; Rosmawati 2018).

As for its territorial geology, Wakatobi is mainly formed by a mainland matrix of coralline lime karsts (Kuenen 1933). This condition produces low soil fertility and depauperate organic materials, which makes it difficult for the Wakatobi people to explore and expand the agricultural sector as their main livelihood. It has forced the Wakatobi people to explore the possibility of living in surrounding areas. Until the present, a maritime tradition has also been known amongst the diaspora of the Wakatobi people in the Moluccas region, Selayar Islands and Nusa Tenggara (Hadara 2006; Hamid 2015, 2016; La Malihu 1998; Zuhdi 2014).

A preliminary investigation into the archaeological perspectives on Wakatobi Islands has given us an understanding of characteristics of the early settlements on the region, the environmental adaptations that have been made on the region, and the historical connections between the region and the Buton Kingdom as of the $13^{\text {th }}$ century. The investigation was framed from the perspectives of archaeology, history and maritime tradition. The archaeological perspective focused on the establishment of fortifications or settlement sites characterized by stone walls. The historical perspective focused on the Wakatobi people's historical roots in their maritime tradition. The maritime tradition perspective was focused on the observation of the Wakatobi people's ethnographic profile.

The present study builds on the preliminary investigation outlined above. The research involved deepening the phases of information gathering through the collection of archaeological, historical and ethnographical data. Archaeological data collection was conducted using the techniques of survey and observation to identify archaeological remains within the research location, including artifacts, features, structures and other archaeological remains. Meanwhile, historical and ethnographical data were collected through literature review and interviews. The latter method was used to collect primary and secondary data in the forms of folklore and oral traditions on the local histories and cultures of Wakatobi. The source of literature or secondary data used as a comparison of the results of our field interviews is a report on the results of data collection on the oral traditions of the people in the Wakatobi Island written by Taalami et al. in 2016. This collection of ethnohistorical data aims to link local oral history with the archaeological data found at the sites. The coordination of data from oral tradition, ethnohistory and archaeology is expected to gain a deeper understanding through creating an integrated narrative (Damm 2005; Beck and Somerville 2005; Flexner et al. 2016). Ethnographic data was also collected regarding local customs, daily routines, traditions, and rituals, mainly in the context of the maritime cultures which are still adhered to by the locals. The next phase involved a descriptive analysis based on the verbal descriptions of archaeological remains along with a spatial analysis to produce information on the 
distributions of these remains. This was performed alongside collation of the historical and ethnographical data so as to describe the historical background related to the maritime traditions of Wakatobi. The final phase was explanation based on results of the data analysis and synthesis so as to describe the profiles of Wakatobi Islands viewed from archaeological, historical and maritimetradition perspectives.

\section{Traditional Fortifications and the Distribution of Archaeological Sites on Wakatobi Islands}

Fortifications have been identified dating from the prehistoric era, especially during the Neolithic era, and built for defence from outside disturbances. The archaeological remains that confirm the fort's origins from the Neolithic period are stone axes and megalithic remains at traditional fortification sites in Way Sekampung (Sumatera). In early times, forts were built in simple forms, with piles of soil encircling a settlement or significant places for protections (Triwuryani 1995). Forts were also used to build European colonial defences, frequently called Colonial Forts. With reference to historical times, the term of Traditional Forts (Mundardjito 2010) or Indigenous Fortifications (Bulbeck and Caldwell 2020) have been introduced to distinguish local forts from colonial forts. Generally, traditional forts have a simple design, and are irregular shape, and adapted to the surrounding environment (Mundardjito 2010; Rinandi and Suryaningsih 2015). Such traditional forts, in the forms of piles of soil, steep hills, or stone arrangements without adhesive materials may be found especially in Eastern Indonesia (the Wallacea Region), such as Otahuta Fort in Gorontalo (Marzuki 2020), the indigenous fortifications or local forts of the South and Southeast Sulawesi mainland (Bullbeck 1992; Hasanuddin 2010a; Bulbeck and Caldwell 2020), Kapahaha, Wawani and Amaiha in Ambon and Saparua islands (Mansyur 2016), and Ujir on Aru island (Handoko 2016), along with fortified settlements of Southeast Maluku and Southwest Maluku (Schapper 2019), and Timor-Leste (O’Connor et al. 2020).

The distribution of traditional forts includes archaeological remains within the territory of Buton Kingdom, including Wakatobi Islands. Settlement sites characterized as traditional forts are found not only in the center of the Buton Sultanate (Wolio Fort), but also dispersed across its periphery such as Kalisusu Fort at Ereke, Koncu Fort, Liwu, Kombeli, Takimpo at Wabula, and similar forts at Baadia, Sangia, Kopea, Kamaru and Lasalimu (Hasanuddin 2010b; Hasanuddin 2020; Mahmud 2014; Sarjiyanto 1999). It is also true for Wakatobi Islands, namely Liya Fort and Kaledupa Fort or Ollo (Rosmawati 2018; Somba 2020).

Survey results from 2019 show that the distribution of traditional forts on the Wakatobi Islands covers the main islands of the region, such as Wangi-wangi, Kapota, Kaledupa, Tomia and Binongko (Table 1). Each of these islands has at least two to five forts, often located on both sides of the island. This distribution also reflects the archaeological perspective of Wakatobi as an area of islands. Below are the descriptions of the forts interspersed with other archaeological remains relevant to Wakatobi Islands as a maritime region. 


\begin{tabular}{|c|c|c|c|}
\hline No. & $\begin{array}{l}\text { Location } \\
\text { (Island Name) }\end{array}$ & Name of Forts & Explanation \\
\hline 1. & \multirow{5}{*}{ Wangi-wangi } & Tindoi & $\begin{array}{l}\text { Remaining wall structures, still intact, and } \\
\text { located on high ground. }\end{array}$ \\
\hline 2. & & Mandati Tonga & $\begin{array}{l}\text { Complete intact structures, located on high } \\
\text { ground. }\end{array}$ \\
\hline 3. & & Liya & $\begin{array}{l}\text { Complete intact structures, located on high } \\
\text { ground. }\end{array}$ \\
\hline 4. & & Ponto Langi & $\begin{array}{l}\text { Complete intact structures, located on high } \\
\text { ground. }\end{array}$ \\
\hline 5. & & Wanci & $\begin{array}{l}\text { Toponym, no observable structures remain, } \\
\text { coastally located. }\end{array}$ \\
\hline 6. & \multirow{3}{*}{ Kapota } & Katiama & $\begin{array}{l}\text { Toponym., minimum structures remain, located } \\
\text { on high ground. }\end{array}$ \\
\hline 7. & & Baluara (Kapota) & $\begin{array}{l}\text { Some structures remain, located on low ground, } \\
\text { coastally located. }\end{array}$ \\
\hline 8. & & Togo Molengo & $\begin{array}{l}\text { Complete structures remain, located on high } \\
\text { ground. }\end{array}$ \\
\hline 9. & \multirow{2}{*}{ Kaledupa } & Palea / Kamali & $\begin{array}{l}\text { Intact structures remain, located on high } \\
\text { ground. }\end{array}$ \\
\hline 10. & & Ollo & $\begin{array}{l}\text { Minimum structures remain (only gates, an old } \\
\text { mosque and tombs), located on high ground. }\end{array}$ \\
\hline 11. & \multirow{3}{*}{ Tomia } & Patua & Perfect wall structures, located on high ground. \\
\hline 12. & & Suo-suo & $\begin{array}{l}\text { Some wall structures remain, located on high } \\
\text { ground. }\end{array}$ \\
\hline 13. & & Lagole or Rambiranda & $\begin{array}{l}\text { Some wall structures remain, located on high } \\
\text { ground. }\end{array}$ \\
\hline 14. & \multirow{8}{*}{ Binongko } & Taduna & $\begin{array}{l}\text { Some wall structures remain, located on } \\
\text { contours of high ground, near a beach. }\end{array}$ \\
\hline 15. & & Baluara (Taipabu) & $\begin{array}{l}\text { Some wall structures remain, located on high } \\
\text { ground }\end{array}$ \\
\hline 16. & & Palahidu & $\begin{array}{l}\text { Some wall structures remain, located on the } \\
\text { contours of high ground, near a beach }\end{array}$ \\
\hline 17. & & $\begin{array}{l}\text { Koncu Pacua Wali or } \\
\text { Koncu Kapala }\end{array}$ & Intact wall structures, located on high ground. \\
\hline 18. & & Wali or Rajawali & $\begin{array}{l}\text { Toponym, no observable structures remain, } \\
\text { coastally located. }\end{array}$ \\
\hline 19. & & Oihuu & \multirow{3}{*}{$\begin{array}{l}\text { Toponym, not surveyed, the inhabitants } \\
\text { informed that the location is on high ground. }\end{array}$} \\
\hline 20. & & Popalia & \\
\hline 21. & & Kolo Mokoro & \\
\hline
\end{tabular}

Table 1: List of Traditional Forts Distributed across Wakatobi Islands. Source: Regional Agency for Archaeological Research in South Sulawesi Province, 2019. 


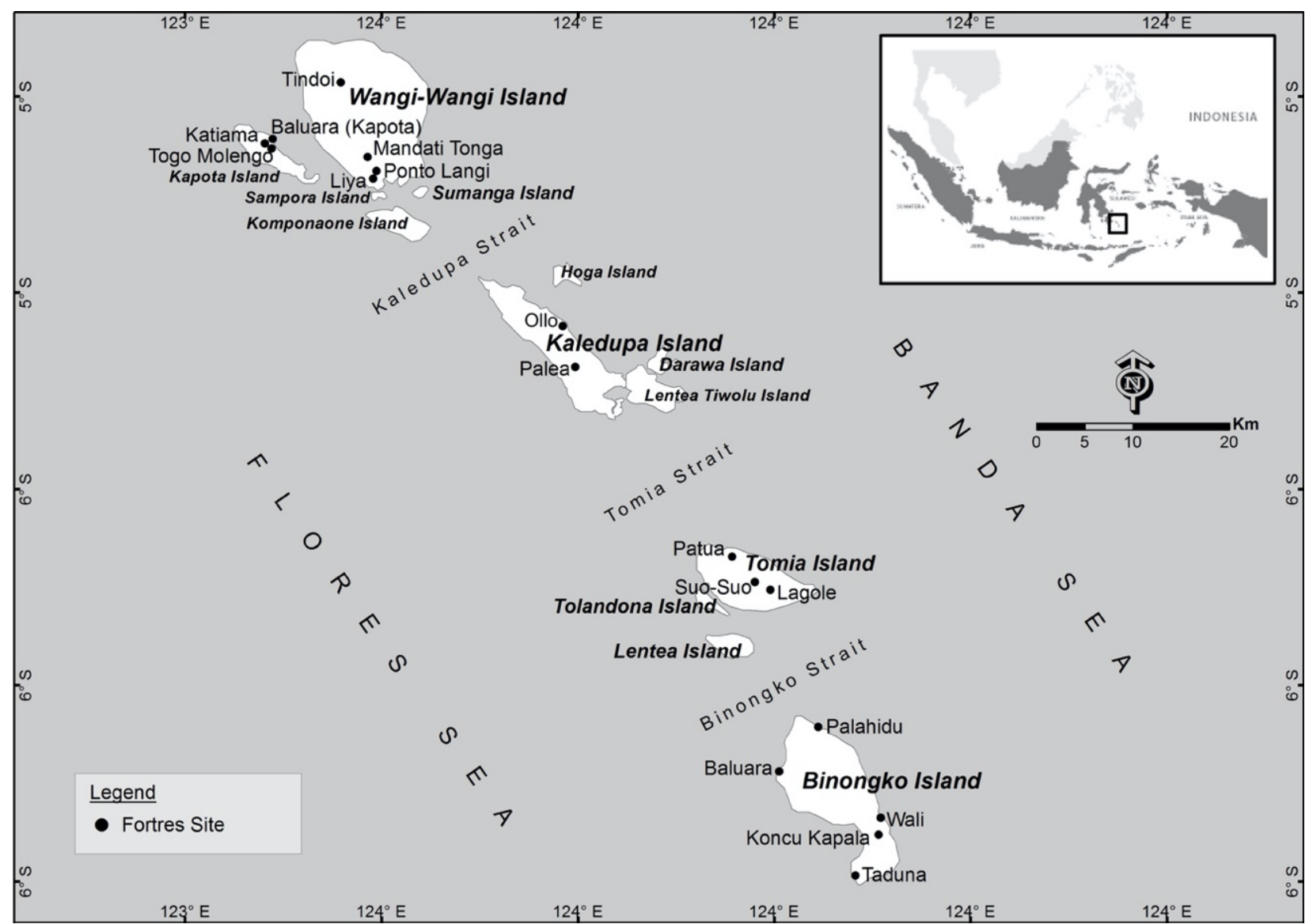

Fig. 1 Distribution of Fort Sites on Wakatobi Islands based on survey results. Source: Regional Agency for Archaeological Research in South Sulawesi Province, 2019.

\section{Islands of Wangi-Wangi and Kapota}

\section{Traditional Forts}

Data on the distribution of Wangi-wangi Island forts covers Tindoi Fort, Mandati Tonga Fort, Liya Fort and Ponto Langi Fort. Observations on the forts' locations show that they are mainly located on high ground or hilltops with an average altitude of 50-70 m asl. If the case of the location of Wanci Fort can be confirmed, then it was the only Wangi-wangi fort located on the coast.

Distribution data also shows the spread of geographical locations from north to south, and centered, within the mainland. It is said that Wanci Fort was located near the Office of Military District Command on Jalan Sudirman, Kelurahan Mandati II, Kecamatan Wangi-wangi, in the downtown area of the city of Wanci. It is said that Wanci Fort was located here, but there are no wall structures left due to the construction of roads and buildings in the area.

Data on the distribution of Kapota Island forts covers Katiama Fort, Togo Molengo Fort, and Baluara Fort. These forts are located at an average altitude of $50 \mathrm{~m}$ asl. Baluara Fort is coastally located. Katiama Fort is difficult to observe because the remains of its wall structures are very few. Katiama fort is located at $5^{\circ} 20^{\prime} 38.13^{\prime \prime}$ S, $123^{\circ} 29^{\prime} 29.14^{\prime \prime} \mathrm{E}$ with an altitude of $51 \mathrm{~m}$ asl. Katiama Fort seems to have been displaced due to vines. There are still observable of archaeological findings at this location including wall structure $50 \mathrm{~cm}$ high, mollusk remains, porcelain fragments and earthenware fragments. The fort is located on high ground and can be used for monitoring the 
waters at the eastern flanks of Kapota Island. The geographic location of all these forts is the central eastern coast of the island. The distribution of forts on Wangi-wangi and Kapota islands can be further viewed in Figure 1.

By observing a contour map, we can see that most of the forts were located on elevated locations. As for the four forts with structural remains on Wangi-wangi island, their landscape conditions show that Tindoi Fort has the most densely packed contours with a minimal flat area. The landscape conditions of Mandati Tonga Fort show that its wall structures were built on a flat plain. This is also the case with Ponto Langi Fort. However, as for Liya Fort, it sits on a flat plain in contrast with the other forts of Wangi-wangi. The area where Katiama Fort is located has a densely packed contour with a minimal flat area. Togo Molengo Fort is located on an area that has a relatively flat contour. Baluara Fort is on a coastal area with a flat contour. Currently, the high ground where Katiama Fort is located is used by the local people for their farms. Meanwhile, Baluara Fort is today located in the center of a settlement.

\section{Lighthouse Complex of Wangi-wangi}

The Wakatobi Islands have been used as a shipping lane for has been knowned since at least the $14^{\text {th }}$ century, as identified in the many historical notes which mention the traditional routes that included these islands. Besides these historical notes, archaeological sites also show that the Wakatobi Islands had a significant role for shipping lanes, as indicated by the lighthouse built during the colonial era at Wangi-wangi Island. The building of the lighthouse is also recognized as the beginning of the modern or colonial shipment era. This lighthouse complex is located in Waha Village, Wangi-wangi Sub-district at 515' 35.5' S and $123^{\circ} 32^{\prime}$ '08.6” E. Its topographic conditions include slopes at an elevation of $134 \mathrm{~m}$ asl. It can be reached by a motorcycle or car, traveling approximately $5 \mathrm{~km}$ from the city of Wanci. The lighthouse was built by the Dutch colonial government and at present is operated under the Kendari District Navigation Office of the Naval Transportation General Directorate, the Ministry of Transportation of Indonesia.

In general, the lighthouse complex consists of several buildings which were built by the Dutch government, namely a lighthouse tower, an office - also used as the guardhouse (see Figure 2), and a water tank. Most of the structures are still original and intact with minor renewal. The renovations includes the stone arrangements built as foundations circling the stairs on the tower legs and also the replacement of the tower lights. The lighthouse light can reach up to 30 nautical miles in range, and our informant also noted that the lighthouse's design is similar to that of the lighthouse located on the island of Selayar (also built by the Dutch Government), which, however, is not operational anymore. The tower construction, meanwhile, is made of iron, and has a hexagonal shape with six iron stanchions plugged onto concrete base foundations. The upper part holds the control room and also supports the circular movement of the light. In the center, there are iron stairs providing the main access to the upper part of the tower. 

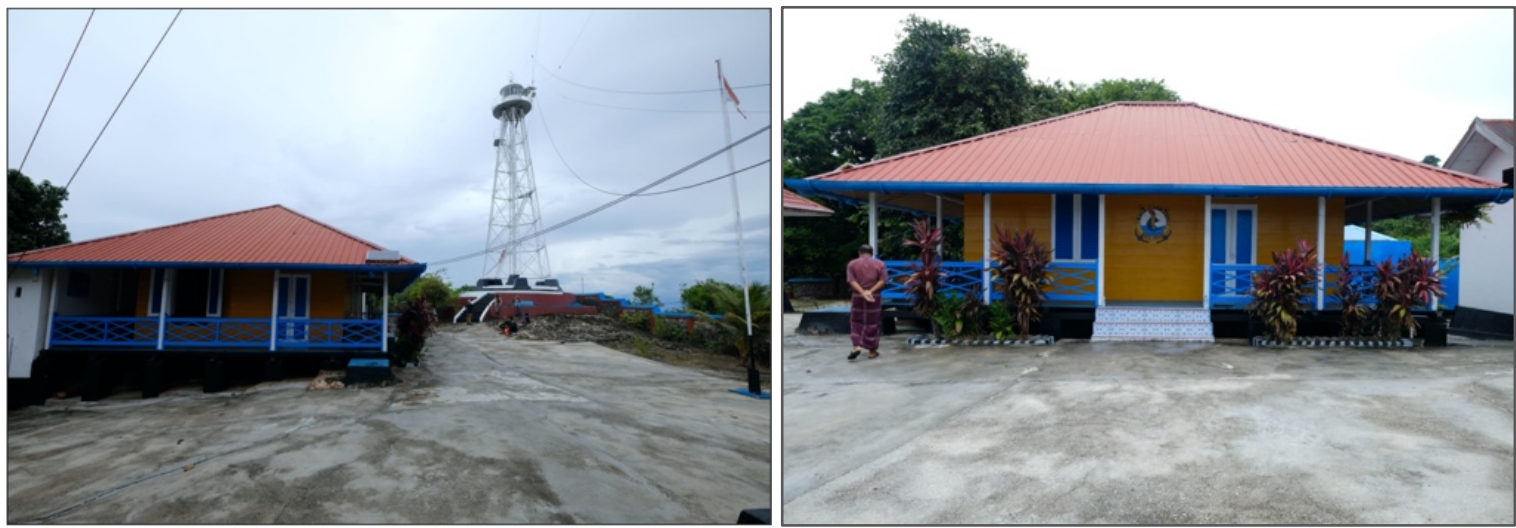

Fig. 2 The Wangi-wangi lighthouse complex built by the Dutch East Indies government; the lighthouse also marks the modern shipping route of Wakatobi. Source: Regional Agency for Archaeological Research in South Sulawesi Province, 2019.

\section{Island of Kaledupa}

Kaledupa, located to the south of Wangi-wangi, has a plain topography, especially in the north part of the island with the highest point on Pangilia Hill at $203 \mathrm{~m}$ asl. Results of a survey show that Kaledupa possesses two forts, namely Palea Fort and Ollo Fort. Both forts are located at $30 \mathrm{~m}$ asl. Palea Fort is located on the southern center of the island, while Ollo Fort is located on the eastern center of the island. The collected oral tradition says that Palea Fort was where the first government of Barata Kaledupa was based and for the next period the government was based in Ollo Fort. Although there was a switch of governmental center, Palea Fort was not abandoned, and in fact, it has still been kept as a settlement until the present. The distribution of forts on Kaledupa can be seen further in Figure 1.

Nowadays, both forts are not intact as both have only portions of wall structures as their marks. For example, Palea Fort has only a square-shaped stone wall structures which in the present day are known as Kamali Fort. These remaining structures are presumed to mark the main hall of Palea Fort as Kamali in the local Buton language means castle. It is also the case that Ollo Fort at present shows only the remains of buildings that seem to have been built more recently or reconstructed as marks of the fort's existence in the past.

\section{Island of Tomia}

Surveys on Tomia Island show a distribution of forts which includes Patua Fort, Suo-Suo Fort, and Lagole Fort. Observations on their location reveal that most are located on high ground or hilltops with an average altitude of 88-298 $\mathrm{m}$ asl. Suo-Suo Fort is located at a higher point compared with the other forts. The forts of Tomia Island are geographically dispersed from the east to the west sides of the island. Each fort tends to be situated centrally in the island (North - South) following the contours of the hills which are located in the central part of the island. Even though Patua Fort is situated on high ground, it is relatively close to the beach line giving it a monitoring capacity over the coastal waters. The distribution of the Tomia Island forts can be further seen in Figure 1.

Patua Fort has semi-circular walls, starting and ending at the north side which utilizes steep cliffs for protection (see Figure 3A). The landscape contours inside the fort are relatively flat and divided into north and south clusters, and the overall area of the fort is 3.14ha. The condition of the ground surface is clearly distinguished by three steps. The first step begins from outside the fort and leads up to the stairs. The second step leads from the stairs through the interior of the second layer of 
wall. The third, highest step leads up to where there are the marks of a mosque foundation. Surface survey revealed two clusters of porcelain and earthenware fragments. Both clusters are relatively dense.

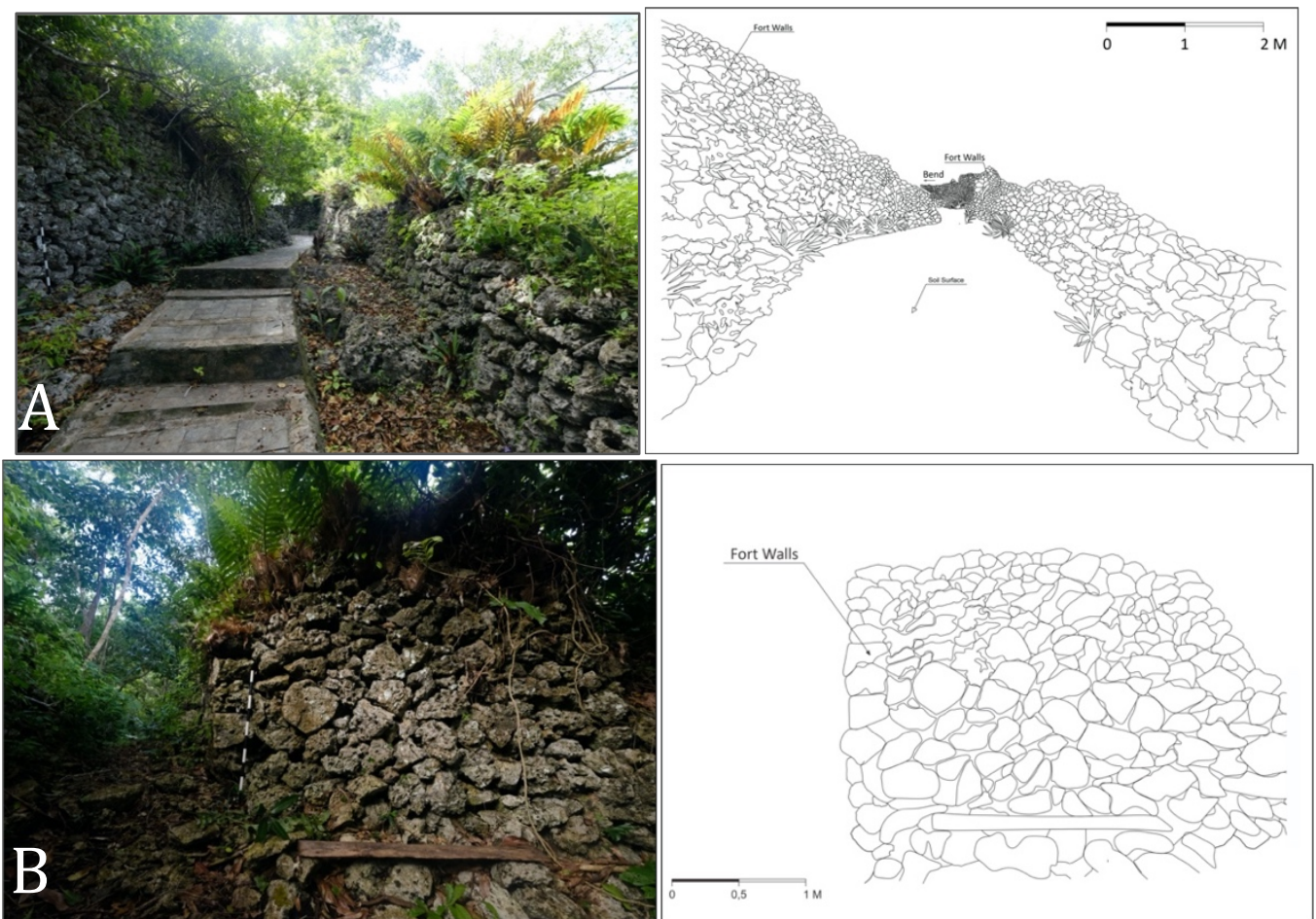

Fig. 3 Walls of Patua Fort (A) and Suo Suo Fort (B) on Tomia Island. Source: Regional Agency for Archaeological Research in South Sulawesi Province, 2019.

As for the condition of Suo-Suo Fort, the only structures left are a bastion (see Figure 3B) and tombs, located on the south side, along with a Lawa and Baruga (gate with traditional roof) also located on the south side, apparently new or reconstructed as a marker of the fort. There are no indications of porcelain nor earthenware. This side of the fort has flat contours, whereas the north side overlooks a steep valley. The walls of coral material disappear into the vines which cover the fort and this, along with the structural defects, makes more detailed observations difficult.

The condition of Lagole Fort is better as the coral-made fort's walls can still be observed. The core hall of the fort is marked by the foundations of a mosque, located at the center, while at the north there are tombs and bastion structures. The distribution of porcelain and earthenware fragments was quite dense inside the fort. The indications of settlement outside the fort's complex were hard to trace owing to the surrounding vegetation of forest with tangled vines. Observations inside the fort indicate that there was a settlement for a small community, focused on the north side which is marked by the remains of a square-shaped stone arrangement along with stone humps. Porcelain and earthenware fragments have a dense distribution in this area.

\section{Island of Binongko}

Binongko Island is located on the south end of Wakatobi Islands. It has a steep topography with its highest point located on Bukit Terpadu at $222 \mathrm{~m}$ asl. Results of a survey of forts on Binongko Island provide data on Taduna Fort, Baluara Fort, Palahidu Fort and Koncu Pacua Wali Fort. Oral information was also gained on other forts on the island; however, the limited research time did not permit extension of the survey to follow up this information. Most of the forts are located on high ground, such as Oihuu Fort, Popalia Fort and Kolo Makoro Fort. Another fort, Wali or Rajawali 
Fort, which is said to be located at the center of the settlement of Kelurahan Wali presents a defective condition. Its wall structures made of compiled coral material are missing as the locals have used the fort's material as housing material. Most of these forts are located on high ground with an average elevation of 5-148 $\mathrm{m}$ asl. The Binongko forts are distributed from the north to the south of the island. The distributions of these forts can be seen in Figure 1.

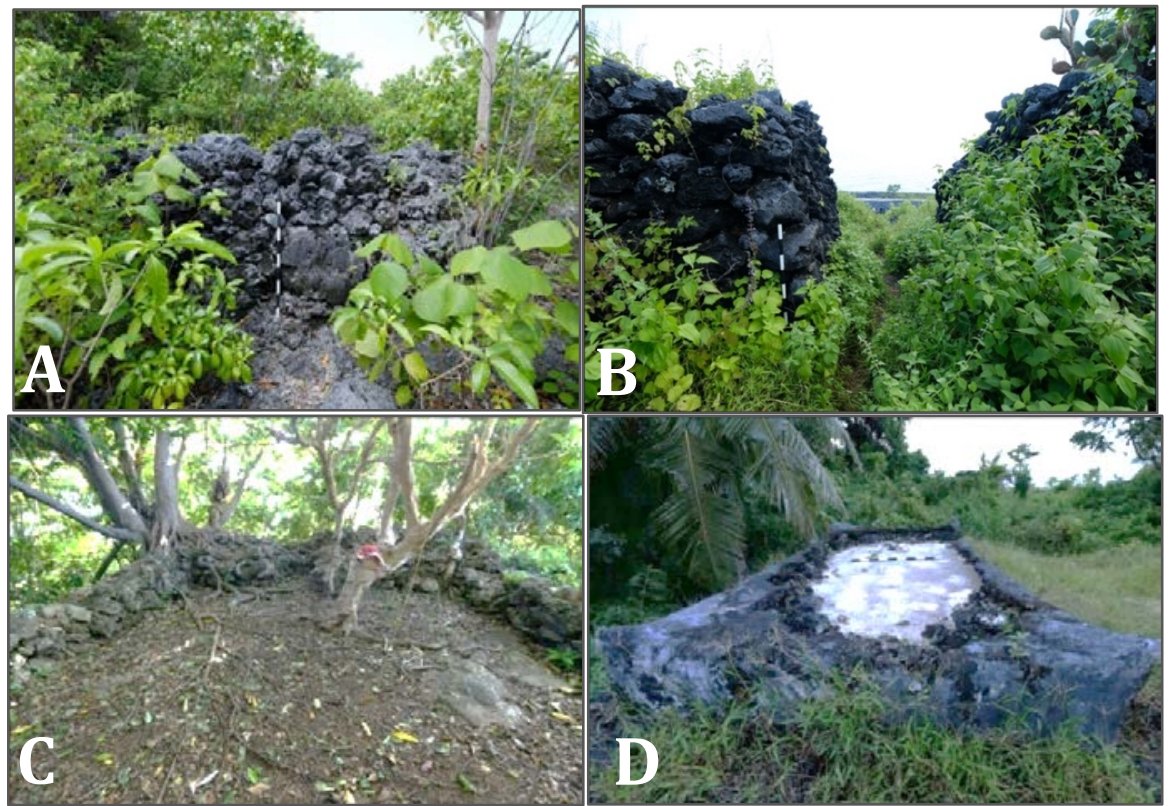

Fig. 4 Ruins of fortified structures on Binongko Island. Stone wall at Baluara Fort (A), Gate (lawa) at Taduna Fort (B). The ruins of a mosque at Koncu Pacua Wali fort (C), and the ancient Tomb at Palahidu Fort (D). Source: Regional Agency for Archaeological Research in South Sulawesi Province, 2019.

Taduna Fort, on the west coast of Binongko Island, is the southernmost fort. This fort is situated on top of a coral hill near the beach line which makes it easier to monitor the coastal waters. The fort's observable wall structures (see Figure 4A) are limited to the front side (the north wall). The interior does not have any separator walls or stone structures for dividing spaces, which suggests that the interior of this fort was not divided into rooms with specific functions. The survey findings include a square-shaped coral arrangement, a presumed tomb, located near the west side of the wall. The interior also has a structure of arranged corals which is also a presumed tomb, along with an opening to a vertical cave. Taduna Fort possesses no encircling wall structures, instead the natural conditions are used such as where the hilly area is located east of the wall. East of the fort is a valley with a wide open plain.

Baluara Fort is located on the hills far from the beach line. However, its position on high ground enables it to monitor the coastal waters to the north and northwest. The observable fort wall structures are the northern wall (see Figure 4A), assumed to be the front face, where there are three entry points. The features found within the fort include a square-shaped coral arrangement presumed to be a tomb. Besides that, on the east side there are also coral structures which seem to have functioned as steps for leveling the ground and also in earlier times to elevate the ground. The distribution of porcelain and earthenware fragments inside the front wall is quite dense.

Palahidu Fort is situated on high ground right next to beach-side cliffs. The wall structure built following the line of beach cliffs functioned as the front wall and has two observable gates. Survey 
shows that this wall structure is broken off from the main gate (see Figure 5) on the southeast side while at the northwest the end of the wall is marked by a square-shaped bastion. Significant finds in the interior of this fort include a square-shaped coral arrangement at the southeast on the east side of the gates and there is a steep-sided tomb (see Figure 4D) south of the gates. An observation of the existing structures shows that the fort seems to be oriented towards the sea located to the east (northeast) whereas the interior of the fort or fort complex is located at the southwest. Currently, the fort's condition and particularly the wall structures are not intact as the axial road track of Binongko has cut through this presumably square-shaped fort.

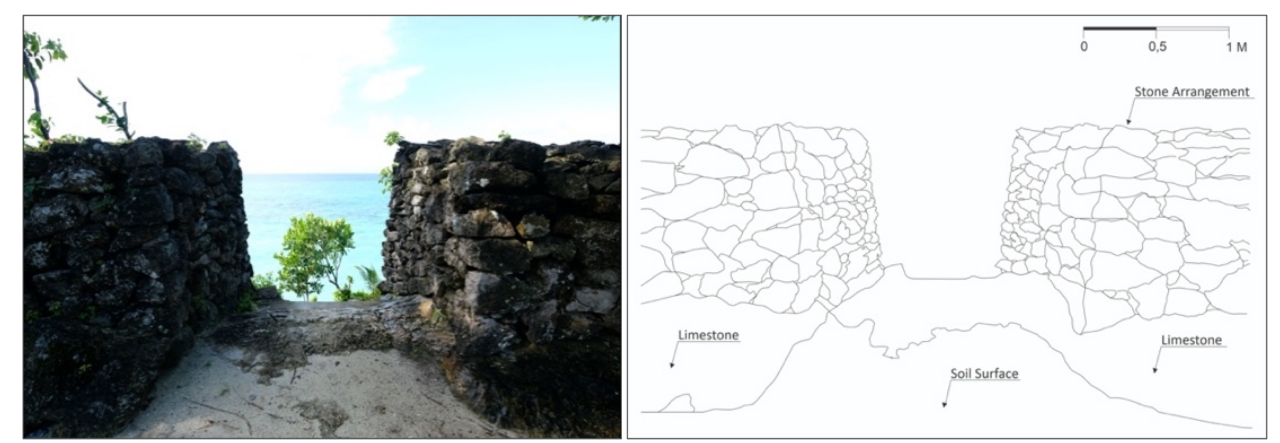

Fig. 5 The Gate (lawa) of Palahidu Fortress. Source: Regional Agency for Archaeological Research in South Sulawesi Province, 2019.

The Binongko survey shows that Koncu Pacua Wali Fort is the only fort located far from the beach line. It is also located on higher ground compared to the other forts. In general terms, the shape of this fort follows the contours of the hills where the wall structures were built on the slopes. A transverse fort wall was also built across the slopes to protect the highest side from Koncu Hill. An observation shows that the fourth wall is located on the east side, while the west side is an area without stones arranged to make a wall. It seems that enough protection was provided by the location of the west wall on top of a steep cliff. The significant finds in the fort are old tombs, cannons, and a structure that used to be the foundation of a mosque on top of the fort (see Figure 4C).

\section{The Spatial Aspect and Relative Dating of Wakatobi's Traditional Forts}

The spatial aspect of the traditional forts of Wakatobi can be seen from the cluster divisions in each of the forts. An observation on the existing structures shows that each of the forts has a main cluster that is marked with sacred features. The sacred feature markers are structures that used to be mosques or tombs. Based on the sacred feature markers, the clusters in the forts are grouped into (i) the main cluster placed in one of the forts' sides, as can be seen in Tindoi Fort (see Figure 6) and Mandati Tonga Fort (see Figure 7) and (ii) the main cluster placed in the middle of the forts, as can be seen in Liya Fort (see Figure 8), Togo Molengo Fort, and Patua Fort (see Figures 9 and 10). The cluster division in the other forts cannot be observed well because the fort's wall structures are not intact. However, a sacred feature marker in the form of mosque remains can still be observed in the Koncu Pacua Wali Fort (see Figure 11), Palea Fort, Ollo Fort, Suo-suo Fort and Lagole Fort. Meanwhile, it seems that Ponto Langi Fort functioned as a defence fort since there are not any sacred features that mark the main cluster. The structures of the other forts are not intact, so it is difficult to know the division of clusters in the fort. These forts are Palahidu Fort (see Figure 12), Ollo Fort, Baluara Fort, and Taduna Fort. 


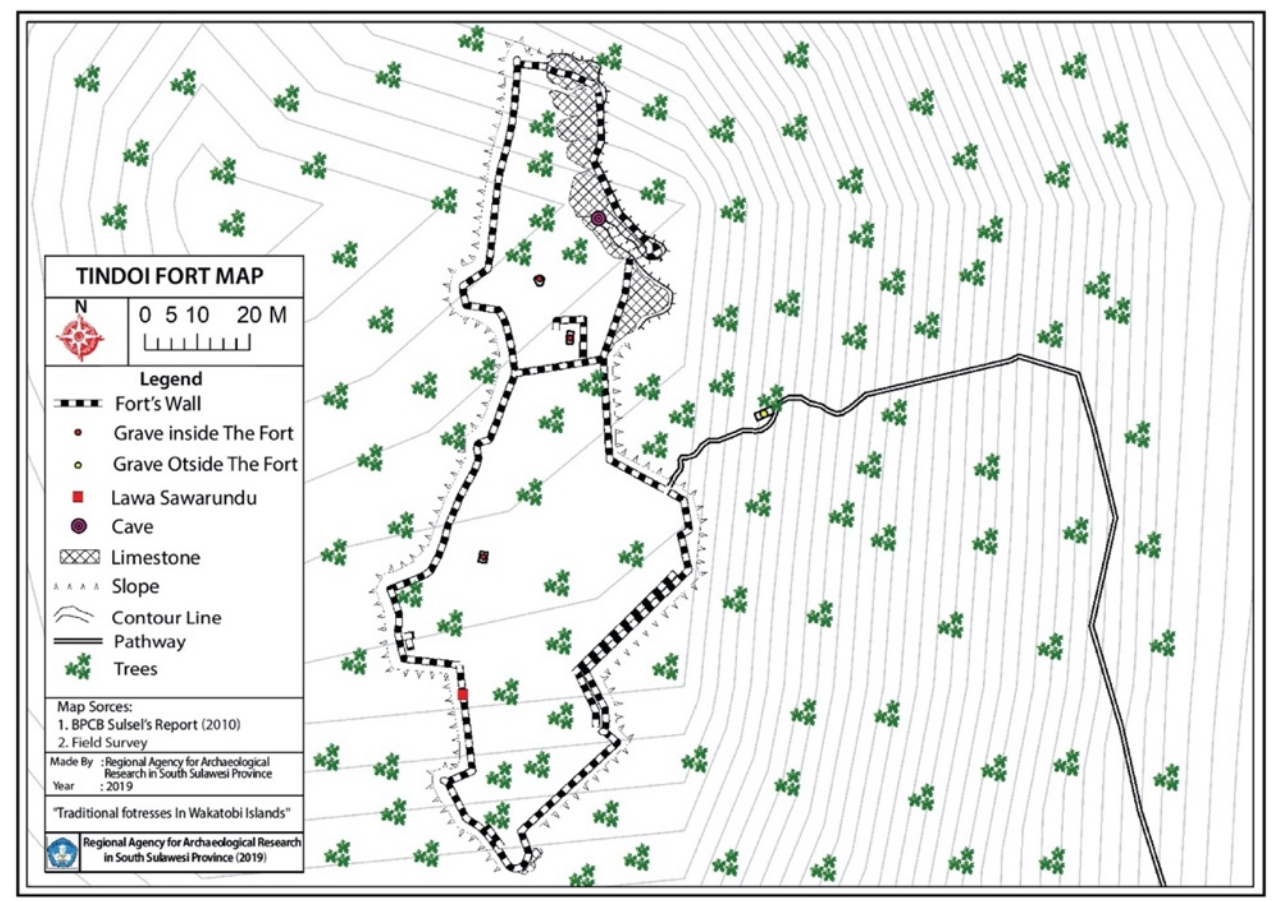

Fig. 6 The Site Plan of Tindoi Fort on Wangi-wangi Island. Source: Regional Agency for Archaeological Research in South Sulawesi Province, 2019.

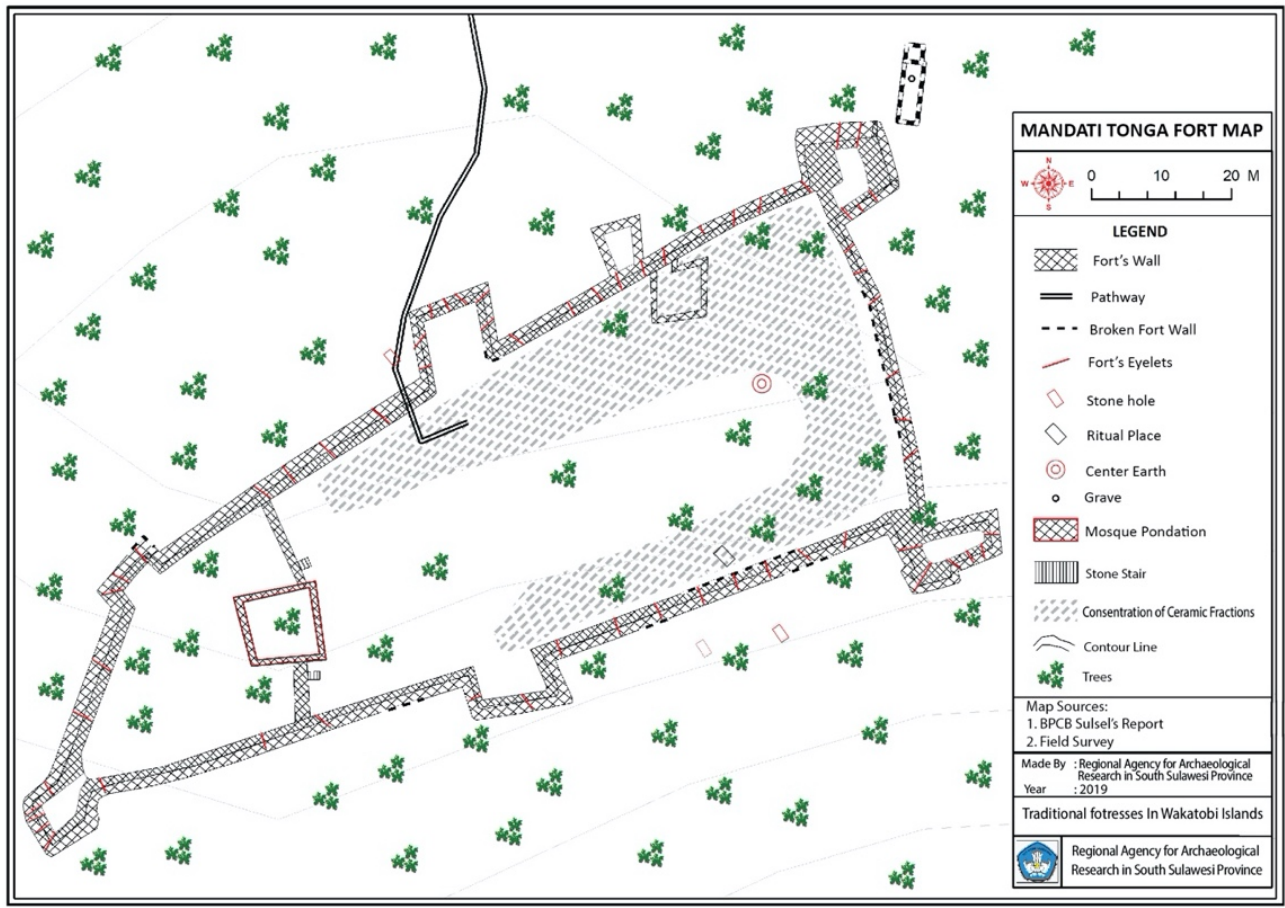

Fig. 7 The Site Plan of Mandati Tonga Fort on Wangi-wangi Island. Source: Regional Agency for Archaeological Research in South Sulawesi Province, 2019. 


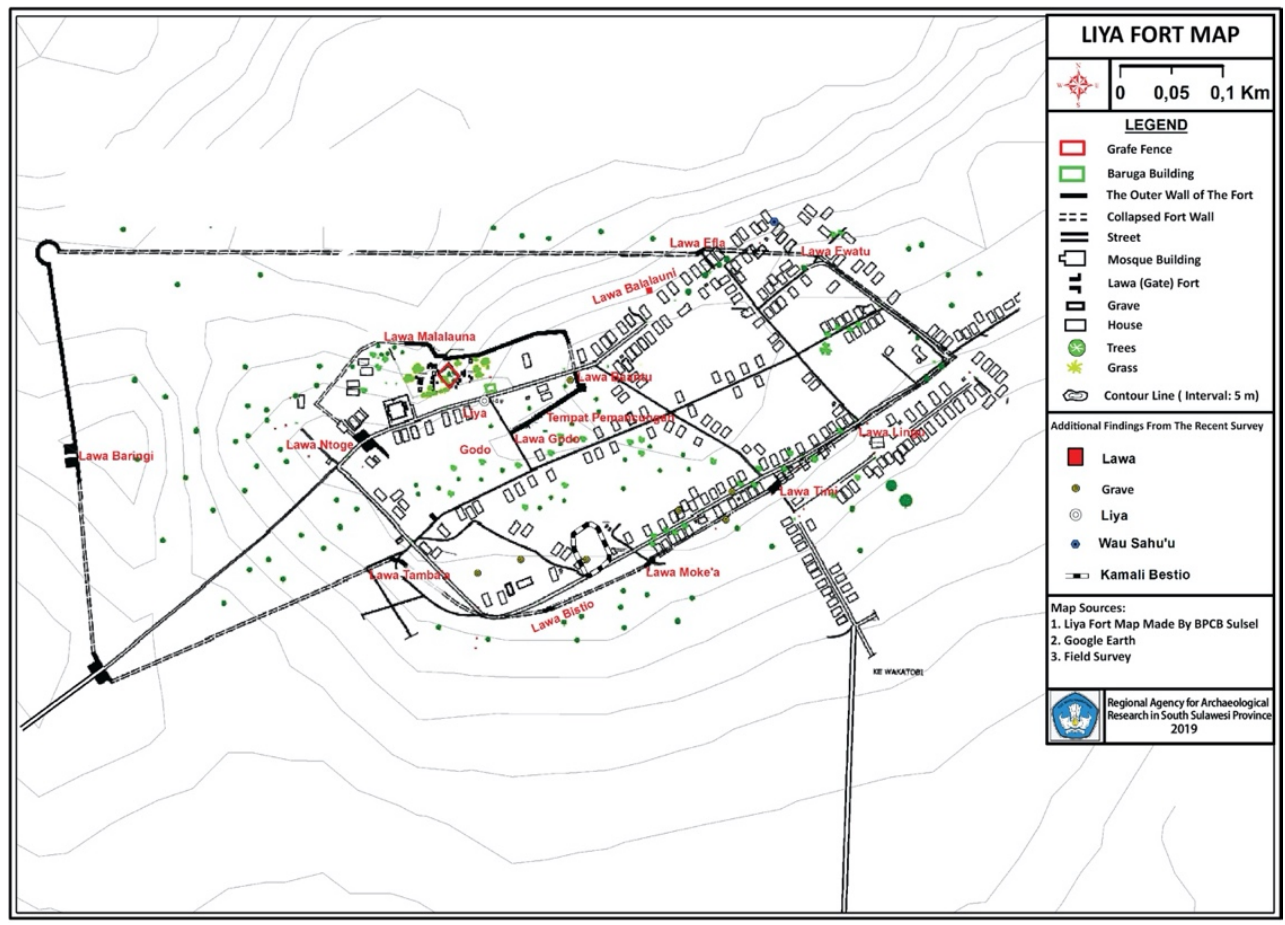

Fig. 8 The Site Plan of Liya Fort on Wangi-wangi Island. Source: Regional Agency for Archaeological Research in South Sulawesi Province, 2019.

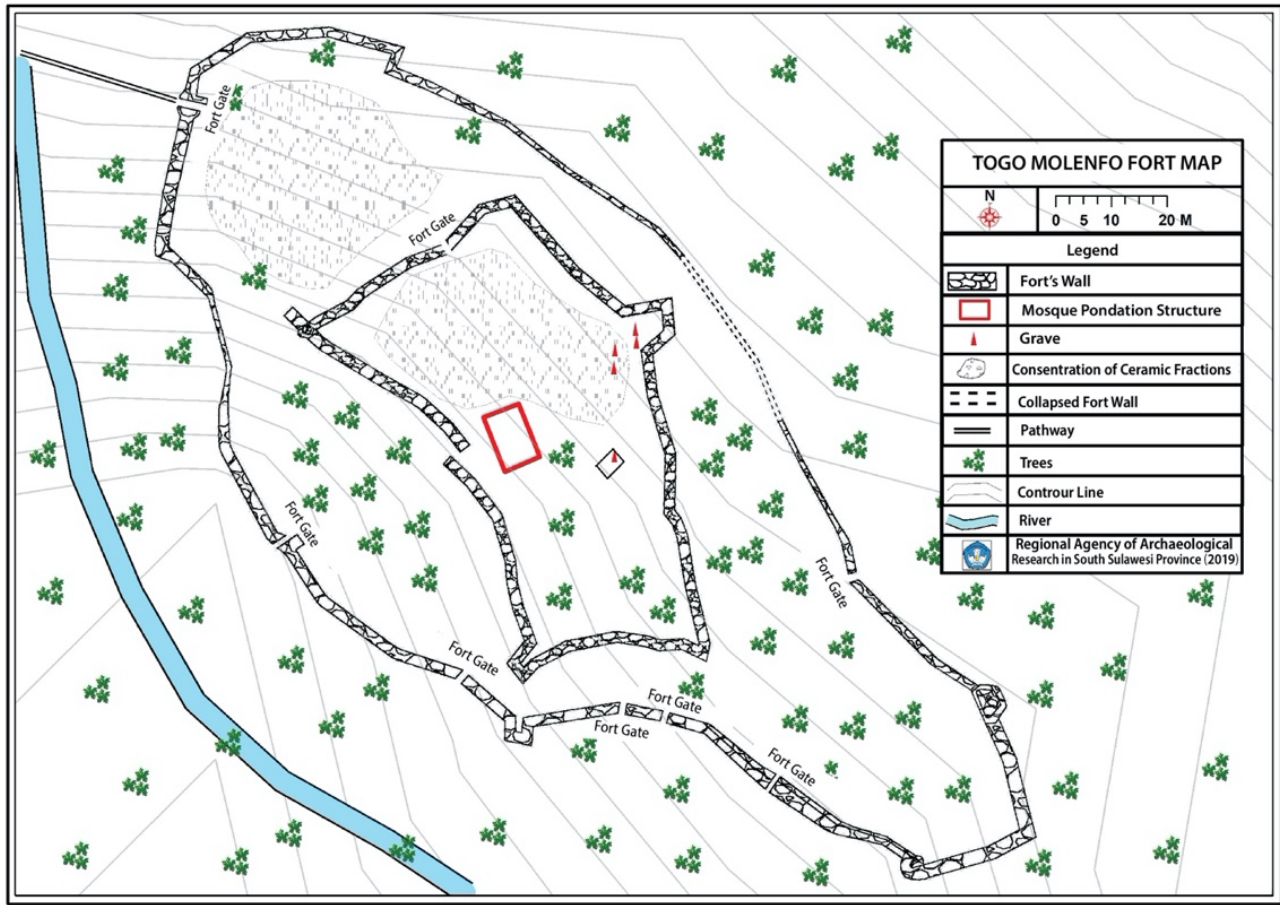

Fig. 9 The Site Plan of Togo Molengo Fort on Kapota Island. Source: Regional Agency for Archaeological Research in South Sulawesi Province, 2019. 


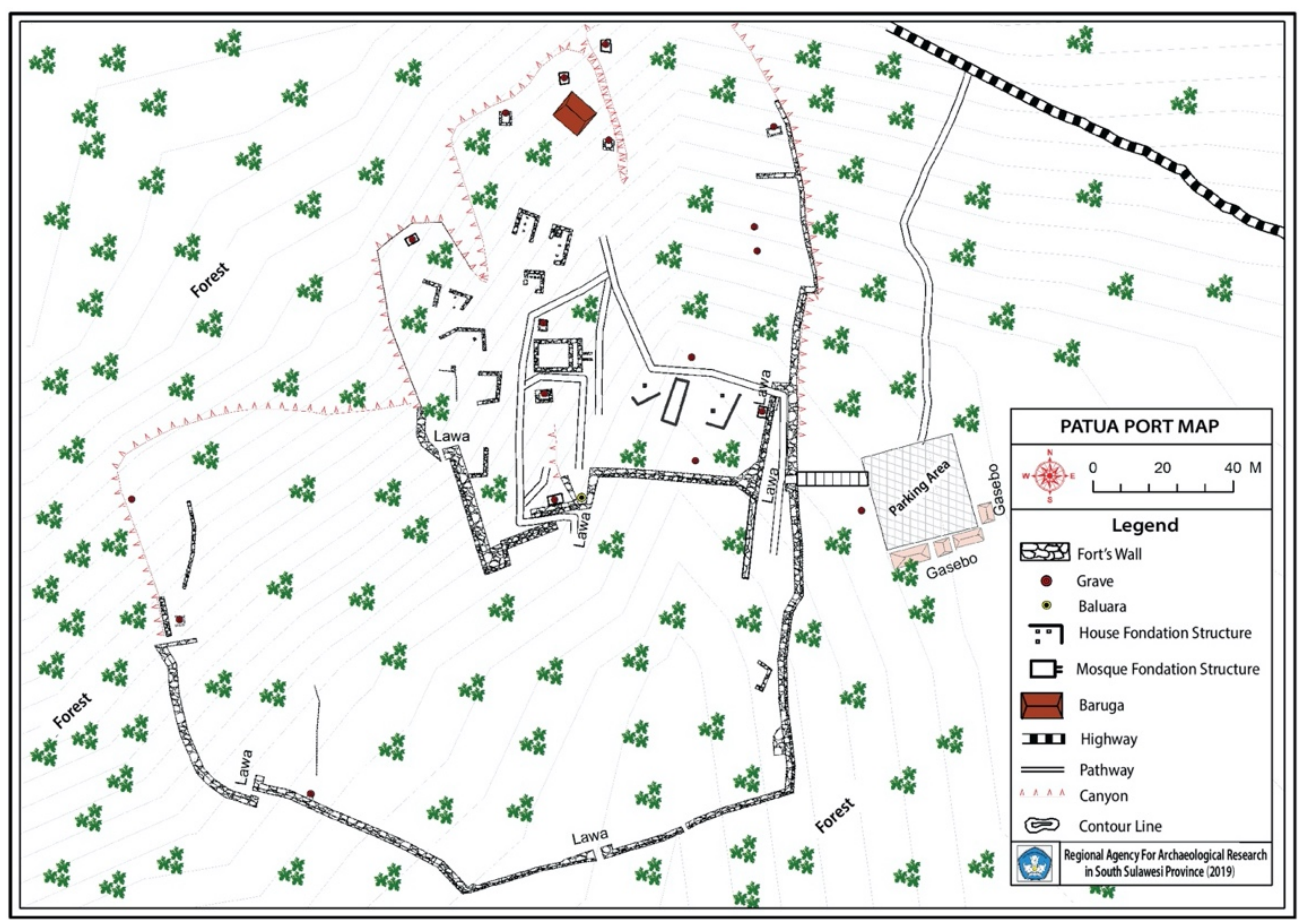

Fig. 10 The Site Plan of Patua Fort on Tomia Island. Source: Regional Agency for Archaeological Research in South Sulawesi Province, 2019.

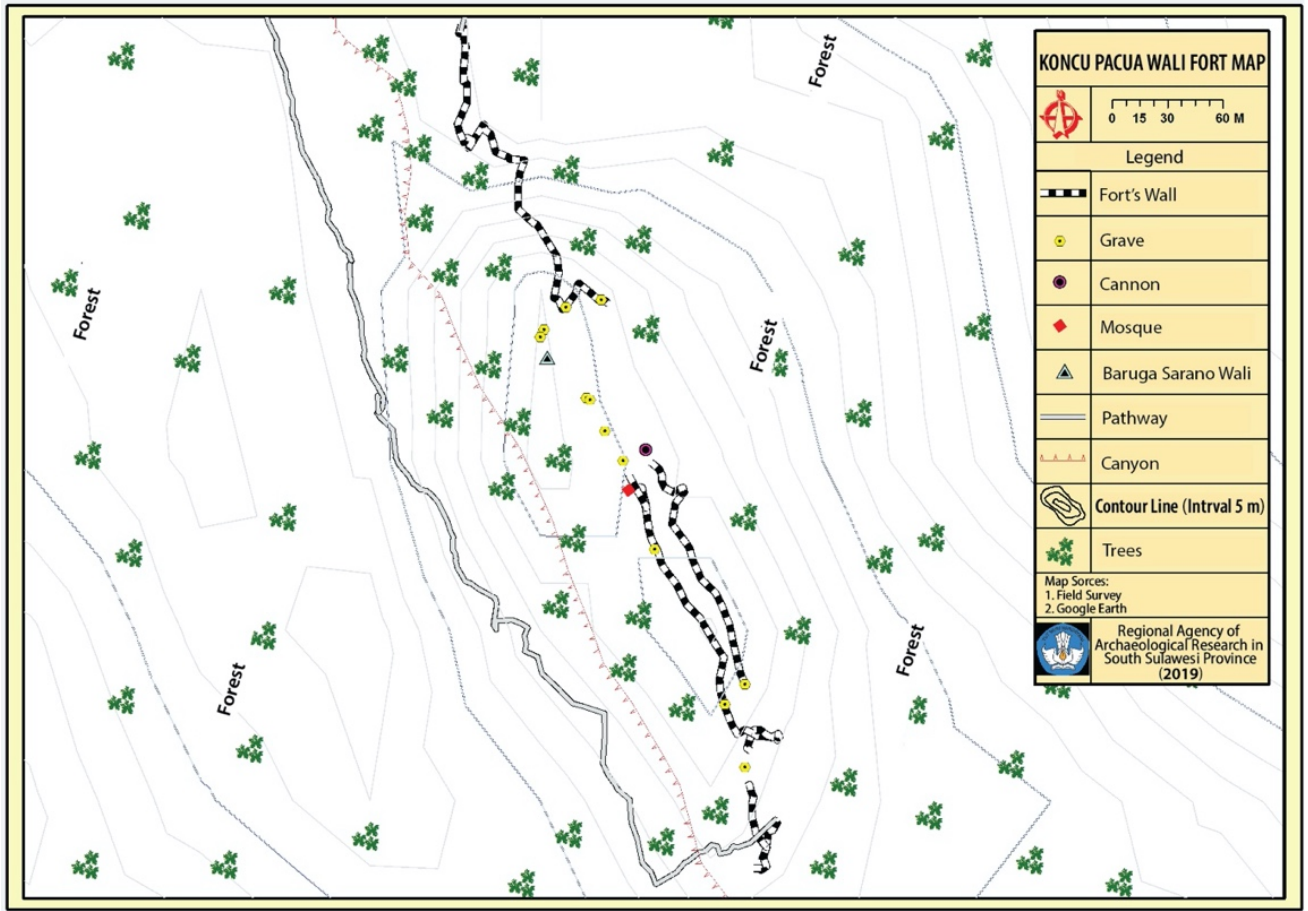

Fig. 11 The Site Plan of Koncu Pacua Wali Fort on Binongko Island. Source: Regional Agency for Archaeological Research in South Sulawesi Province, 2019. 


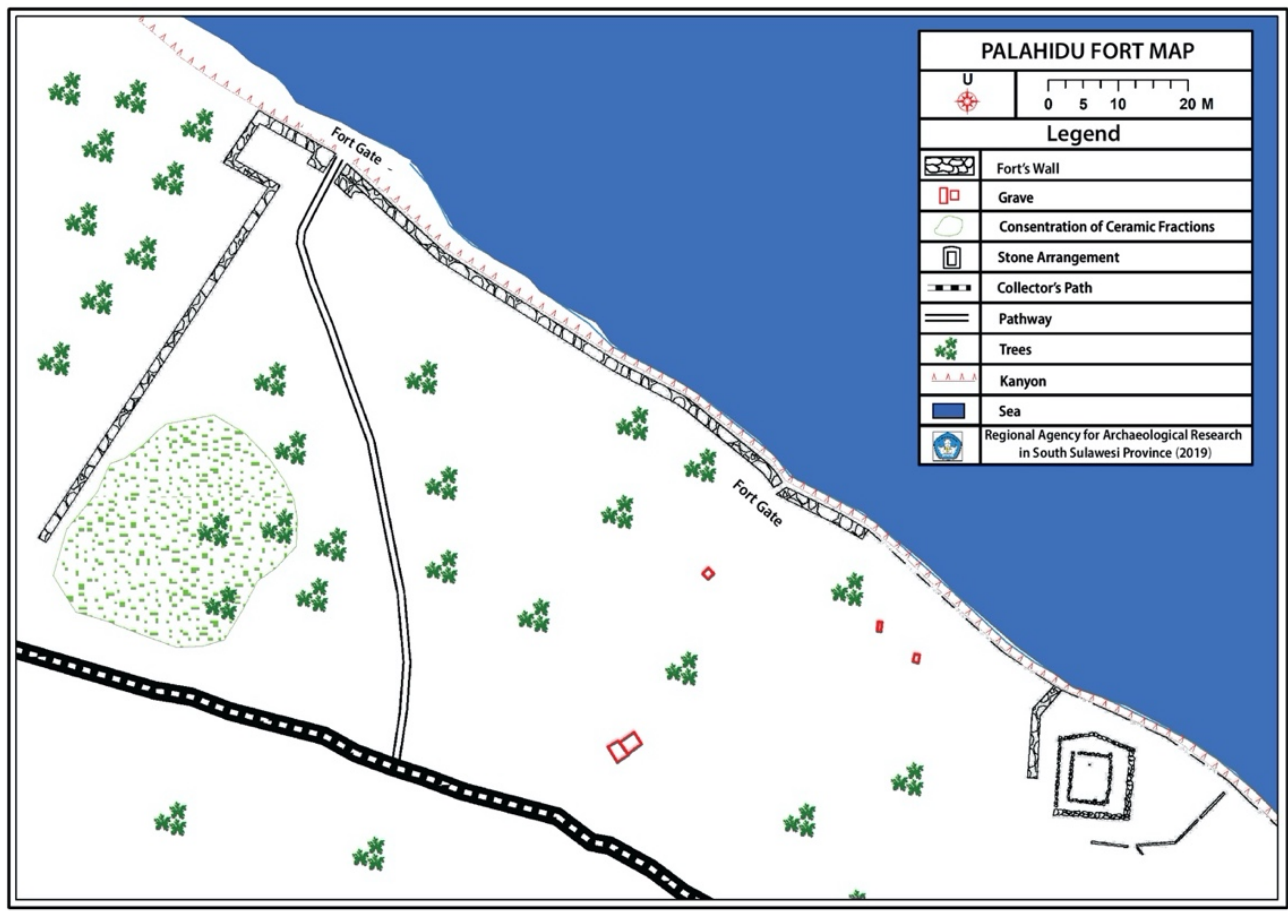

Fig. 12 The Site Plan of Palahidu Fort on Binongko Island. Source: Regional Agency for Archaeological Research in South Sulawesi Province, 2019.

Archaeological surveys also show some characteristics of the ancient settlements on Wakatobi Islands, where traditional forts became important elements in those settlements. Settlement indications can be seen from traces of the settlements in the forms of porcelain fragments, earthenware, and remains of shells for consumption dispersed not only inside but also outside the forts' complexes. This fact shows that the settlements were not only centered inside the forts' complexes but also dispersed outside the complexes. Furthermore, the location of lawa (fort gate) refers to the naming of the settlements. This can be seen clearly in Liya Fort (on Wangi-Wangi Island) and Suo Suo Fort and Lagole Fort (on Tomia Island). Such a settlement pattern shows that the settlements inside the forts, especially the main cluster, are settlements for certain groups of people.

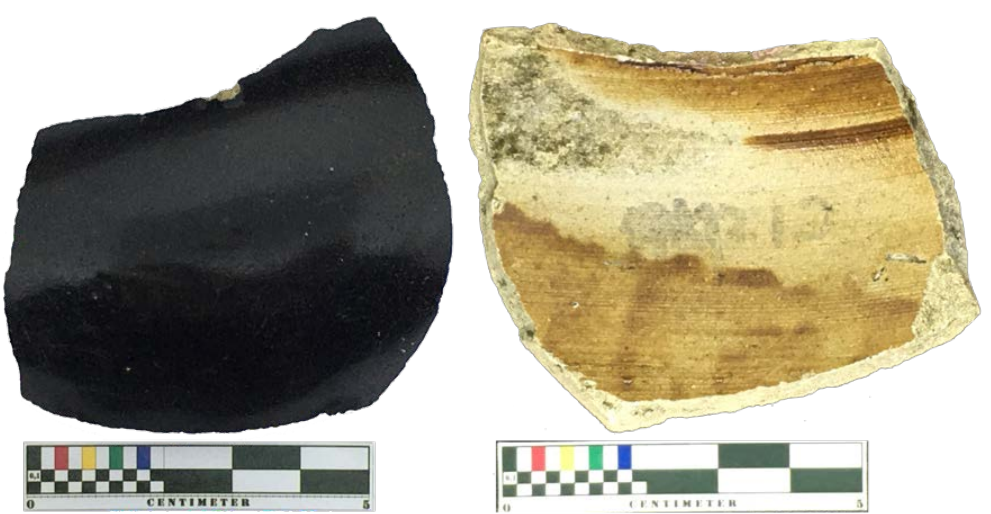

Fig. 13 Vietnamese-Annamese ceramic finding (Taduna Fort, Binongko Island). Source: Regional Agency for Archaeological Research in South Sulawesi Province, 2019. 

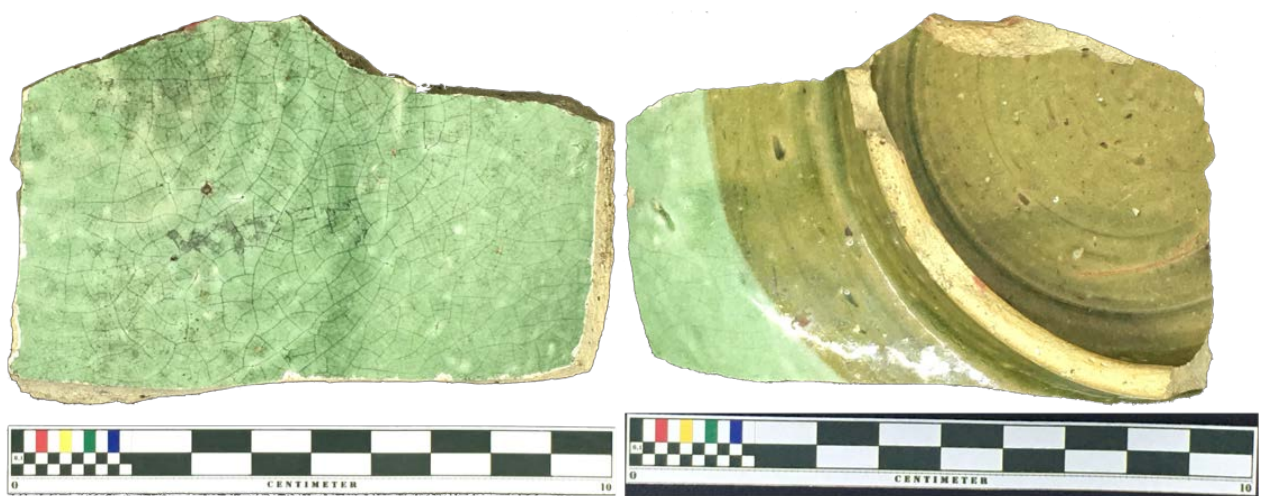

Fig. 14 Vietnamese Celadon ceramic finding (Ollo Fort, Kaledupa Island). Source: Regional Agency for Archaeological Research in South Sulawesi Province, 2019.
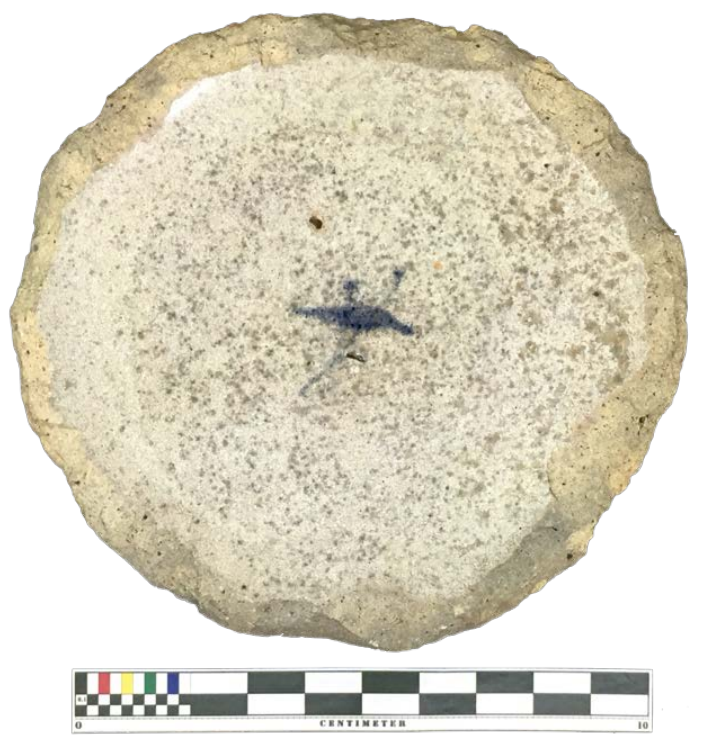

Fig. 15 Thailand Si-Satchanalai ceramic finding (Taduna Fort, Binongko Island). Source: Regional Agency for Archaeological Research in South Sulawesi Province, 2019.
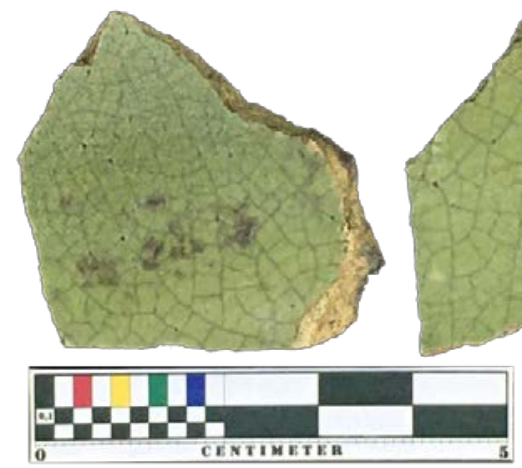

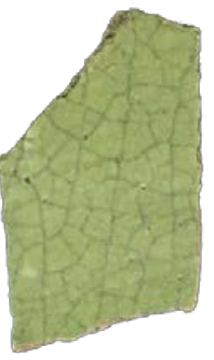

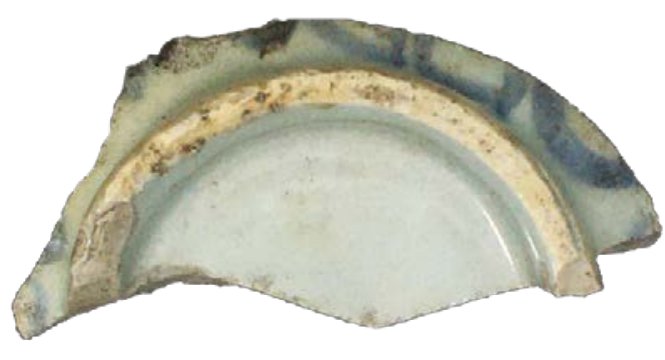

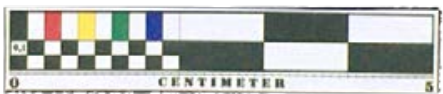

Fig. 16 Ming-16 ${ }^{\text {th }}$ Celadon ceramic finding (Ollo Fort, Kaledupa Island) and Ming Swatow ceramic finding (Mandati Tonga Fort, Wangi-wangi Island). Source: Regional Agency for Archaeological Research in South Sulawesi Province, 2019. 
Furthermore, the ceramic remains found in the traditional fort sites in Wakatobi are surface finds most of which were found around the tombs. Considering that the old tombs become the locations of rituals that have been performed until present time, it can be assumed that the ceramic remains used to be parts of the rituals. Therefore, the dating data that we are presenting are relative based on the ceramic finds in the traditional fort sites. The identification that we have conducted on the ceramic data shows the dates of the ceramic remains from at least $15^{\text {th }}$ century, with ceramics from the Ming dynasty (the $16^{\text {th }}$ and $17^{\text {th }}$ centuries) being the most dominant. Annamese-Vietnam ceramics $\left(13^{\text {th }}\right.$ to $16^{\text {th }}$ centuries) (see Figure 13 and Figure 14) were found in Ollo Fort and Taduna Fort, and Si Satchanalai-Thailand $\left(13^{\text {th }}\right.$ to $15^{\text {th }}$ centuries) (see Figure 15) were found in Taduna Fort. Meanwhile, ceramics from the Ming dynasty $\left(16^{\text {th }}\right.$ century) (see Figure 16) and Qing dynasty were found in Mandati Tonga Fort, Liya Fort, Baluara Fort, Ollo Fort, Patua Fort, and Taduna Fort. The ceramics found are not only from China and Southeast Asia (Vietnam and Thailand) but also from Europe. Apart from ceramics, we also found a Qing dinasty coin (see Figure 17).

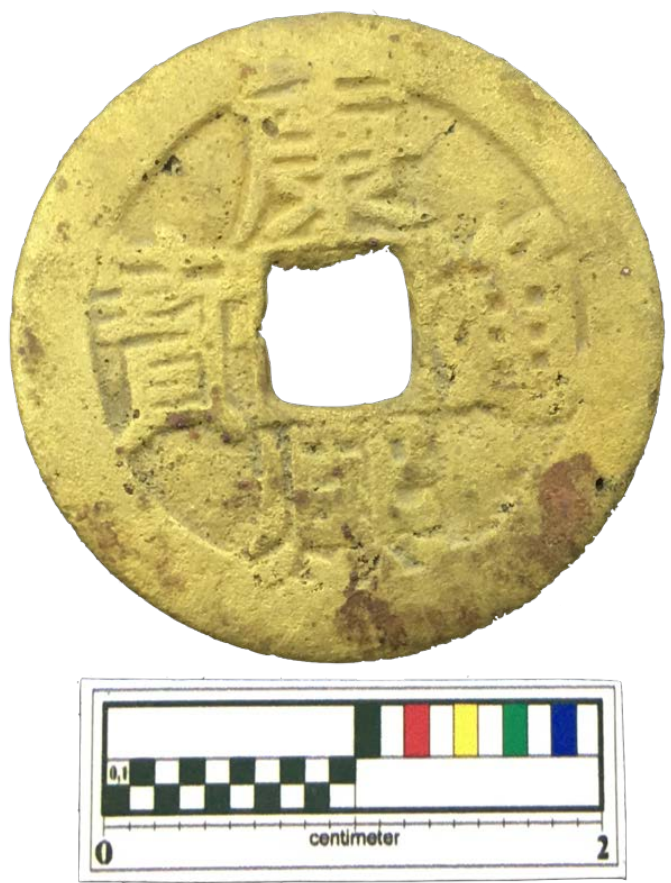

Fig. 17 A Chinese coin of the Qing period $17^{\text {th }}-18^{\text {th }}$ century (Ollo Fort, Kaledupa Island). Source: Regional Agency for Archaeological Research in South Sulawesi Province, 2019.

\section{Wakatobi Islands: Historical Perspective and Maritime Tradition}

In the past the Wakatobi Islands was part of the Buton Sultanate territory and that the term Butonese also included the inhabitants of Wakatobi (Zuhdi 2014:123). Before the arrival of the VOC (Dutch East India Company), the region was known as Liwuto Pataanguna, which in the Wolio language means Four Islands. It was also popularized as Liwuto Pasi, which means Coral Islands (Hamid 2016). Since the VOC period it has been known as "Kepulauan Toekang Besi”. This named is related to Tulukabesi, a warrior of Tanah Hito at Ambon (Maluku) who along with his followers was exiled by the VOC to Wakatobi Islands in the early $17^{\text {th }}$ century (Abubakar 1999; Rosmawati 2018:57; Zuhdi 2014:126-7). Wakatobi local tradition (especially the one on Wangiwangi Island) also says that the name "Wangi-wangi" came from the ancient seamen who noted that one of the islands had a fragrant smell (wangi) of cloves every time they passed by its waters (Zuhdi 2014). 
"Den 31 Januari 1667 sloot Speelman op het jacht Tertholen met den koning van Boeton, La-Simbatta, een kontrakt, waarbij deze zich verbond, om op alle onder zijn gezag staande Toekangbësi eilanden, voornamelijk op Kaledoepa en Wantji-wantji (Wangi-wangi), en voorts op alle andere eilanden, al behoorden die niet tot de Toekang-bësi eilanden, ook op Binongko, ten overstaan van door de Compagnie daartoe te zenden personen alle nagel-en notenmuskaatboomen te zullen doen omvellen en uitroeien, ....” (Ligtvoet 1878: 53-4).

The above citation is part of an article titled "Beschrijving en Geschiedenis van Boeton", written by A. Ligtvoet in 1878, which describes Buton. It also gives information about Wakatobi Islands around the $17^{\text {th }}$ to $19^{\text {th }}$ centuries, which shows the significant role of Wakatobi within a trading network at the time. This trading network had a role not only in the cruise lanes, but also in the context of the spice route as the Wangi-wangi and Kaledupa islands of Wakatobi were spice sources. The citation shows that in January 1667, Cornelis Janzoon Speelman, an admiral of the VOC's war fleet, managed to make an agreement with La Simbata, one of Buton's rulers at the time. One of the articles of the contractual agreement was the compliance of Buton in eradicating cloves and nutmeg (hongitochten) trees in places under its authority, including Wakatobi Islands. The agreement on Hongitochten continued to 1709 (Ligtvoet 1878), and until 1766, on each contractual agreement with Buton, the VOC kept renewing the article regarding Hongitochten (Suryadi 2018:238; Zuhdi 2010).

Speelman's notes on the agreement with the Buton's ruler in 1667 certainly become important information which shows the important role of Wakatobi Island in the Spice Routes. Wakatobi Island, especially Wangi-wangi and Kaledupa, was a source of spices. Certainly, this information needs to be corroborated since other sources mention that cloves were originally from five islands in North Maluku, namely Ternate, Tidore, Moti, Makian, and Bacan (Andaya 1993; Pires 1515 in Cortesão 1944; Pigafetta 1524; Reid 2011). Around the $15^{\text {th }}$ century, clove trees started to be planted in regions south of those islands, especially Hoamoal in Seram Barat. Around the $17^{\text {th }}$ century, the VOC planted clove trees on the island of Ambon and the surrounding areas (de Graaf 1977; Mansyur 2014b). With regards to all this, there is an important fact that clove and nutmeg plants grow in a small part of Wangi-wangi Island, in the village of Posalu to be exact, near Tindoi Fort.

Historical facts regarding the role of Wakatobi Islands as part of the Spice Routes were also described by Ligtvoet. Ligtvoet (1878: 54) mentioned that, according to Speelman's notes, Binongko Island was held by Makassar before being returned to Buton's authority. Makassar's control over Binongko Island can also be related to trading shipment activities from Makassar to Maluku. As is well known, the activities of Makassar traders in Maluku were very intense as of the beginning of the $17^{\text {th }}$ century (de Graaf 1977:73; Dix Grimes 2006: 144; Leirissa 1973: 92;

Mansyur 2013: 48, 2014a: 32, 2014b: 90-1; Rumphius 1910). Binongko Island was a transit point for Makassar traders before they continued sailing to Maluku (Buru, Seram, and especially Hoamoal and Ambon). After the Bungayya Treaty on November $18^{\text {th }}, 1667$, between the VOC and Makassar, rights to the eastern Indonesian region including Buton were excluded from Makassar's authority (Ricklefs 2001: Suryadi 2009: 58).

Another historical fact regarding Wakatobi as a cruising path connection can be found in the account by Ligtvoet (1878: 66) that the Wakatobi Islands (Toekang Besi) were in a tug-of-war 
between Buton and Ternate before Makassar came along. The involvement of Ternate was linked to its interest in expansion during the $16^{\text {th }}$ century, under Sultan Baabullah who was expanding his territory as far as Bima. Wakatobi Islands along with the surrounding region within Buton territory were also included in the expansion of the Sultan of Ternate who was known as The Ruler of 72 Islands (Andaya 1993).

It seems that the effects of Ternate's expansion into Buton territory, including Wakatobi Islands, were deeply rooted, which can be seen from their oral tradition and local government structures. Oral tradition of the Liya of Wangi-wangi states that the founders of Liya Togo, who were four friends, studied gaining supernatural power on their journey to Ternate (Taalami 2016: 51). This tale positioned Ternate as the center of Supernatural Powers which can also be interpreted as the center of authority of the East Region at the time. There is also the myth of Bikusagara within the creation of kinship relations between the rulers of the East Region of the archipelago - Bacan, Buton-Banggai, Loloda and Papua (Andaya 1993).

Another ethno-historical source that reveals the interrelationship between domains is the oral tradition regarding the arrival of newcomers from various domains across Wakatobi Islands. Taalami (2016) summarizes the written sources and oral tradition regarding the accumulation of inhabitants of the Islands of Wakatobi. The newcomers, who are mentioned as occupying every island of Wakatobi, were ethnically Butonese, Malay, Manggarese, Adonaran, Arab and Calcutta Indians, among others (Taalami 2016: 64 and 154). Meanwhile, Susanto Zuhdi (2014) described the related migration by Butonese (including Wakatobi Islanders) to Maluku as "the return of the followers of Tulukabesi” to their homeland (Zuhdi 2014: 243-5). The Tulukabesi followers mentioned in oral tradition as deployed to Wakatobi were Patipelong or Kapitan Patipeilohi in Tomia along with the Kapitan Waloindi at Binongko ${ }^{1}$. Another oral tradition says that a descendant of a Majapahit ruler who married the first princess of Buton was subsequently exiled to Tomia ${ }^{2}$. Hadara (2015: 14-6) also gathered another oral tradition stating that the Wakatobi inhabitants originated from stranded seamen from all over the place who later inhabited these Islands. These stranded seamen were from Maluku (mainly Ternate, Buru, Ambon and Banda Islands), Nusa Tenggara (mainly NTT), the Buton mainland, Sulawesi, and even from Java, Sumatra, Johor and South Philippine islands such as Sulu and Mindanao.

As for governmental structures, each domain of Wakatobi Islands had its own structure with reference to the Buton Sultanate. Liya, for example, had the rank called Bobato Mancuana as the King's Advisor in charge of the East Region Defence, even though the Bobato Sampolawa in charge of governing the East Region was located in Wolio ${ }^{3}$. As for the Lakina Wali structure of Binongko, the highest authority who supervised the Bonto Popalia and Bonto Wali along with the Jou Palahidu was located in Palahidu ${ }^{4}$. It seems that the position of Bonto Bopalia within these governmental structures was reserved for the community of Mbeda-beda speakers, whereas the Bonto Wali was reserved for the community of Cia-cia speakers. The position of Jou was instituted for the representative of each Binongko village. Even though the influence of the Buton Sultanate was very strong, the names of Liya's Bobato and Binongko's Jou have their counterparts in the North Maluku Sulatanates (Ternate and Tidore). The term of Bobato in the Buton Sultanate refers

\footnotetext{
${ }^{1}$ Pers. Comm: Syaifuddin, 24 April 2019.

${ }^{2}$ Pers. Comm: Ferdiang Agung, 25 April 2019.

${ }^{3}$ Pers. Comm: La Ode Adi, 16 April 2019.

${ }^{4}$ Pers. Comm: La Rabu Mbaru, 23 April 2019.
} 
to a leader of a domain, similar to the Bobato of the Ternate Sultanate, while the Tidore Sultanate Jou was the term to refer to its customary council (Andaya 1993).

In general terms, the Butonese have a strong maritime life, as reflected in their model for their Kingdom referred to as a perahu or boat (the Ship of the State). As described by Susanto Zuhdi (2010), the Sultanate of Buton has long described its nation as a boat called a barata. The Barata boat is a type of traditional boat balanced in the water with double outriggers using two clips (the term barata itself) on each side of the boat. The "outrigger of a boat" concept of balance in the Buton Sultanate's philosophical base can be seen in their territorial organization. In the past the Buton Sultanate territory included Tiworo, Muna, Kalisusu and Kaleduppa. These four domains were grouped into two main domains called the barata, whereby Timoro and Muna were the barata in charge of maintaining the West, and Kalisusu with Kaledupa were in charge of the East. The functions of both barata were the simultaneous balancing elements of the Buton Sultanate for managing its territories (Zuhdi 2014: 123 and 213).
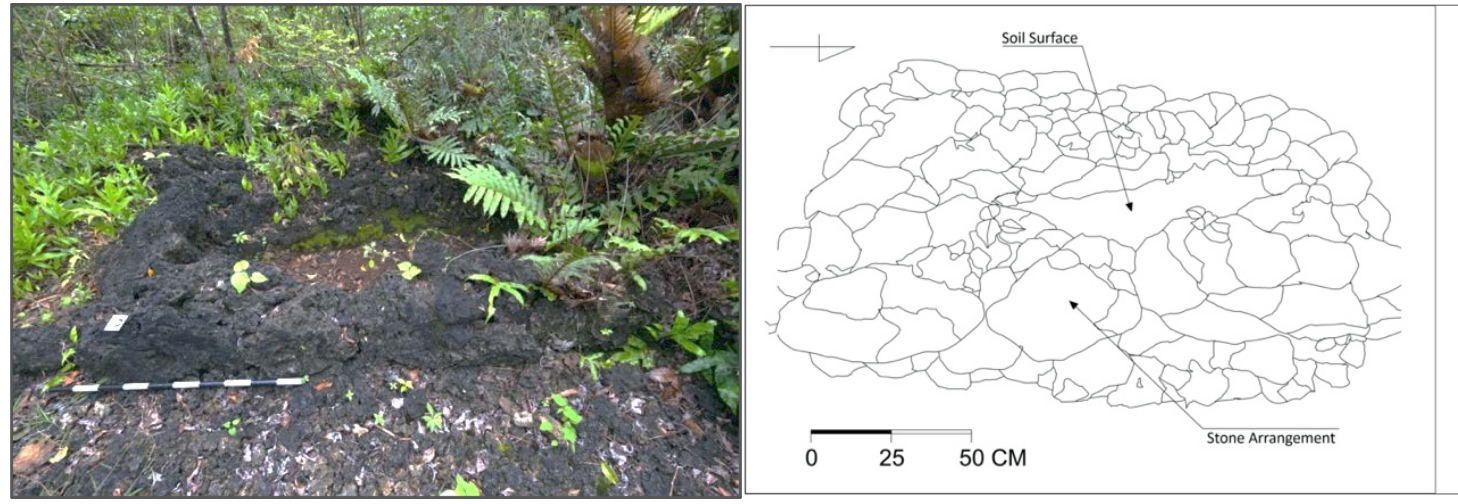

Fig. 18 The Tomb of Wasuru Baende at the Mandati Tonga Fort. Source: Regional Agency for Archaeological Research in South Sulawesi Province, 2019.

The maritime traditions of the Wakatobi people are also depicted in Ligtvoet's note that a traditional custom of the residents of Binongko, Tomia and other Wakatobi Islands was to seek an occupation in Maluku. Later, Ligtvoet also referred to the documents of the Governor of Maluku circa 1861 which was a plea to the Governor of Celebes to ask the Sultan of Buton to permit the residents of Wakatobi Islands to work on nutmeg plantations at Banda after the eradication of slavery by the Dutch East Indies Government (Ligtvoet 1878: 110-111). The existence of the Butonese as workers on Banda Island nutmeg plantations can be traced back to $17^{\text {th }}$ century, when the plantation owners (Perkenier) employed people from outside Banda, i.e., Java, Makassar and Buton (Hanna and Alwi 1983; Andaya 1991; Loth 1995; Mansyur 2011; Suryadi 2018). Maritime traditions of the Butonese, especially the relationship between the Wakatobi people and Banda, apparently can be traced earlier. It is linked to the oral tradition about the arrival of Wa Suru Baende $^{5}$ (or Wasuru Baenda), a princess from Banda, along with her followers escaping a volcanic eruption on their homeland around the $15^{\text {th }}$ century (Abubakar 1999; Hadara 2015: 15). The tomb of the princess is believed to be located in Mandati Tonga Fort on the island of Wangi-wangi (see Figure 18).

\footnotetext{
${ }^{5}$ Pers. Comm: Adianto, 16 April 2019.
} 
The Wakatobi people are known for their voyaging tradition and for working overseas. The profile is reflected in their cruises and tradition of wandering overseas. Until now, this Wakatobi ethnographic profile tends to include an option for working or wandering overseas. As the expression of this trend amongst the Binongko communities, the Mbeda-beda language speakers (Kaumbedha) have chosen Bonerate (Selayar), while the Cia-cia speakers have chosen to migrate to Banda, Ambon, Seram and Fak-fak ${ }^{6}$.

The seafarer character is also represented in the craftsmanship of Binongko communities, especially the Mole in building the Bangka and Boti types of boat. Today, these peoples are also recognized as sailing as far as Halmahera Island and Seram (Maluku), to trade for logs and bring them to Flores. This cargo of logs is usually traded for everyday necessities in Surabaya or Makassar. Besides that, the Binongko people often market their handicraft merchandises (such as the Parang Binongko or Binongko Machete) or pandanus mats in Maluku, sometimes exchanged for sago. It is also true that the Cia-cia of the Lamangingi village community set sail on boats from Mandar as far as Australia. Regarding the relation between Binongko and Maluku, there is this Kabanti or oral tradition that states “Kolekole arumbai kole, Raja Pati dari Tanah Bara”, meaning "boat and canoe, Raja Pati from the West"7. The sailing activities of the Wakatobi people, especially the Binongko people, extend to Singapore and Malaysia where they are known as traders of copra and second-hand goods (Hamid 2016). In their voyage home, the Binongko sailors often carried stoneware jars (see Figure 19).

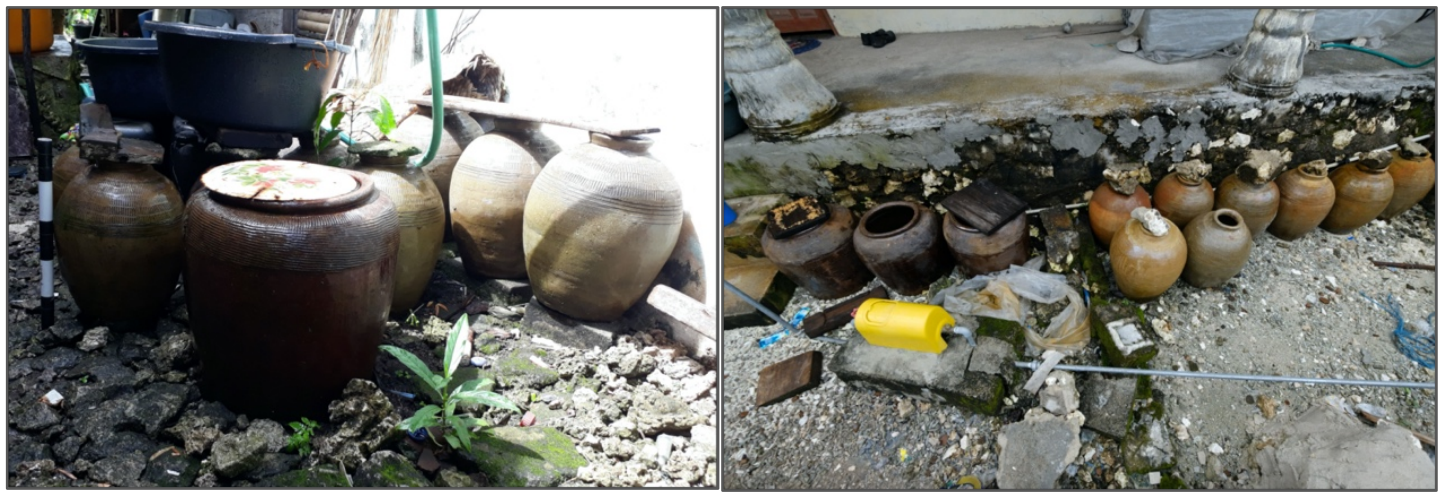

Fig. 19 Stoneware jars carried by the Binongko sailors while sailing from Singapore. Source: Regional Agency for Archaeological Research in South Sulawesi Province, 2019.

Each community of the Wakatobi people possesses unique characteristics in terms of their overseas specialty. It is said the Binongko tend to survive overseas, while the people from Wanci have a term of Waniance, which means hoped-for, in recognition that the Wanci people tend to return home to their homeland ${ }^{8}$. The Tomia are characterized as overseas traders, while the people from Kaledupa are better known as seamen. At the present time, the migration of Tomia people has spread to Maluku, especially Buru Island and the Sula Islands.

\section{Maritime Tradition and its Correlation with Archaeological Traces}

In terms of working overseas and the ethnographic profile of the Wakatobi people, until today it is still under the influence of local beliefs and a mystical mindset. The Wakatobi people still believe

\footnotetext{
${ }^{6}$ Pers. Comm: La Halibu, 21 April 2019.

${ }^{7}$ Pers. Comm: La Halibu, 21 April 2019.

${ }^{8}$ Pers. Comm: La Rabu Mbaru, 23 April 2019.
} 
that old tombs possess a supernatural power called moori. These tombs are usually found in the traditional fort locations of each of the main islands. Each fort has at least one sacred tomb where pilgrims bringing various offerings come and pray motivated by varied wishes.

Besides picturing a mindset and system of beliefs, the ethnographic profile of the Wakatobi people also depicts a strong maritime tradition. Various rituals and ceremonies still practiced by the Wakatobi people indicate that their lives are oriented towards overseas wandering, with rituals performed as an encouragement and spirit for their success overseas. The tradition takes form in dances and songs which also represent their life overseas, for examples, Lariang Dance, Sajomoane Dance and Banda Dance. Another example is one ritual frequently performed by the Taipabu people of Binongko Island which is called the Joajo Taupina or betel nut ceremony. The ceremony contains a prayer often said when sea yields lessen. The ceremony is performed by offering traditional cakes such as cucur (fritters), bananas, betel nut, chicken eggs, coconut, red rice and betel. The procession begins with a prayer at a certain agreed place (generally in a hanta (field) near a mosque or dock). Afterwards, the ceremony continues with discharging the offering in the sea (padongkae). Another ritual is Joajo Pasira, which contains a special prayer for healing sick children ${ }^{9}$.
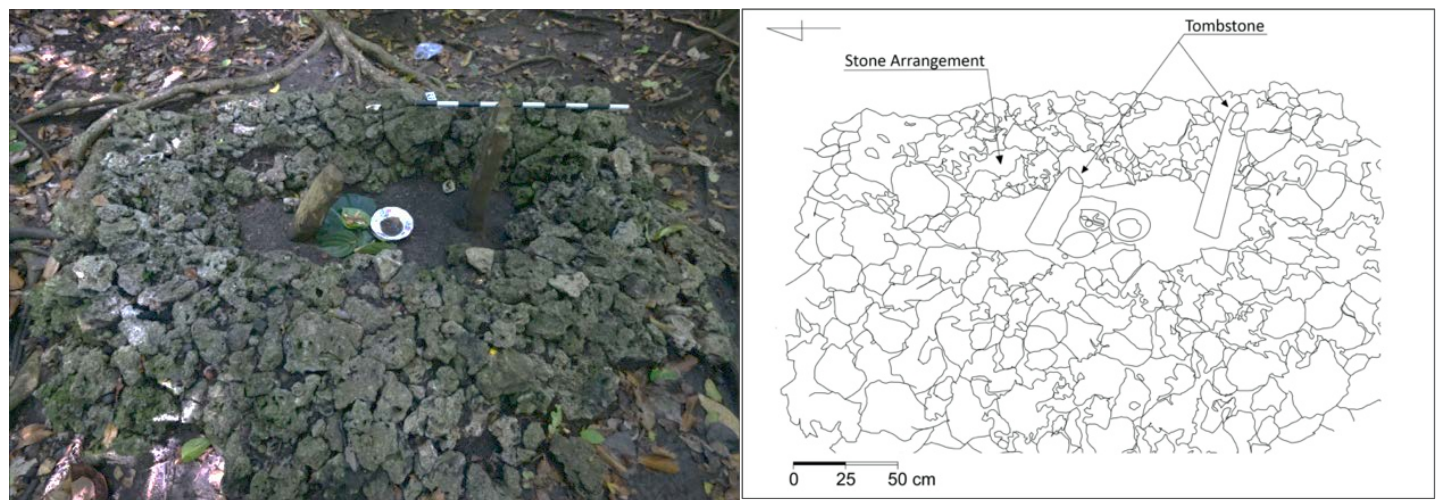

Fig. 20 Ancient tomb with heaped stone at Tindoi Fort. Source: Regional Agency for Archaeological Research in South Sulawesi Province, 2019.
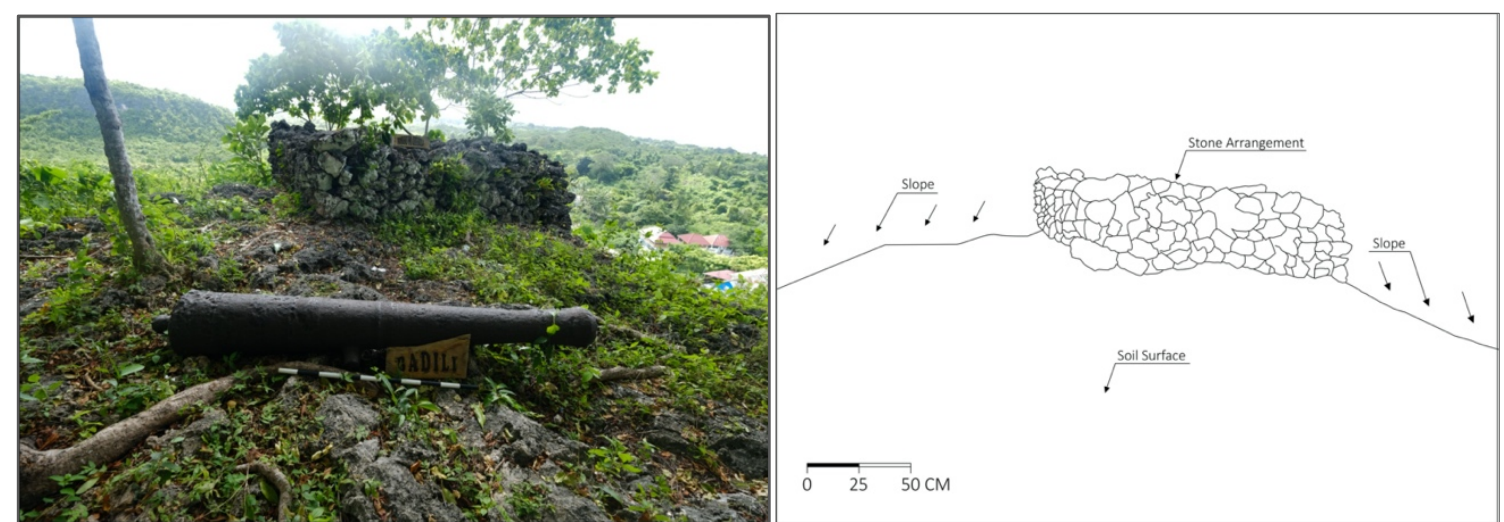

Fig. 21 Ancient tomb with heaped stone and ancient cannon at Patua Fort. Source: Regional Agency for Archaeological Research in South Sulawesi Province, 2019.

${ }^{9}$ Pers. Comm: Rahmat La Mudia, 23 April 2019. 
Tindoi Fort, located on top of Tindoi Hill on Wangi-wangi Island, is still visited by locals to pray and make various wishes, due to the beliefs that the Tindoi hilltop is a sacred place. In this location there are several tombs inside and outside of the fort complex which are utilized as ritual places (see Figure 20). The Wangi-wangi locals even have a saying or bhatata (a form of traditional rhyme containing a wish to the Maker): “.....e moori,....Barakati Tindoi ke Maleko, helaisi aku te dhao helaisi aku te balaa...” meaning "O God, Tindoi and Maleko are sacred, keep me from bad things”. This phrase is frequently said on behalf of the Wangi-wangi who are overseas to boost their spirits or to suggest they hope for a better life (Taalami 2016: 74). Thus, the Tindoi Fort ritual is closely related with maritime traditions and the tendency of the locals to work overseas. Besides that, those who live near the fort staunchly maintain various traditional customs including the maintenance of the water sources near the fort, and the prohibition against wearing red colored items when visiting Tindoi Fort ${ }^{10}$.

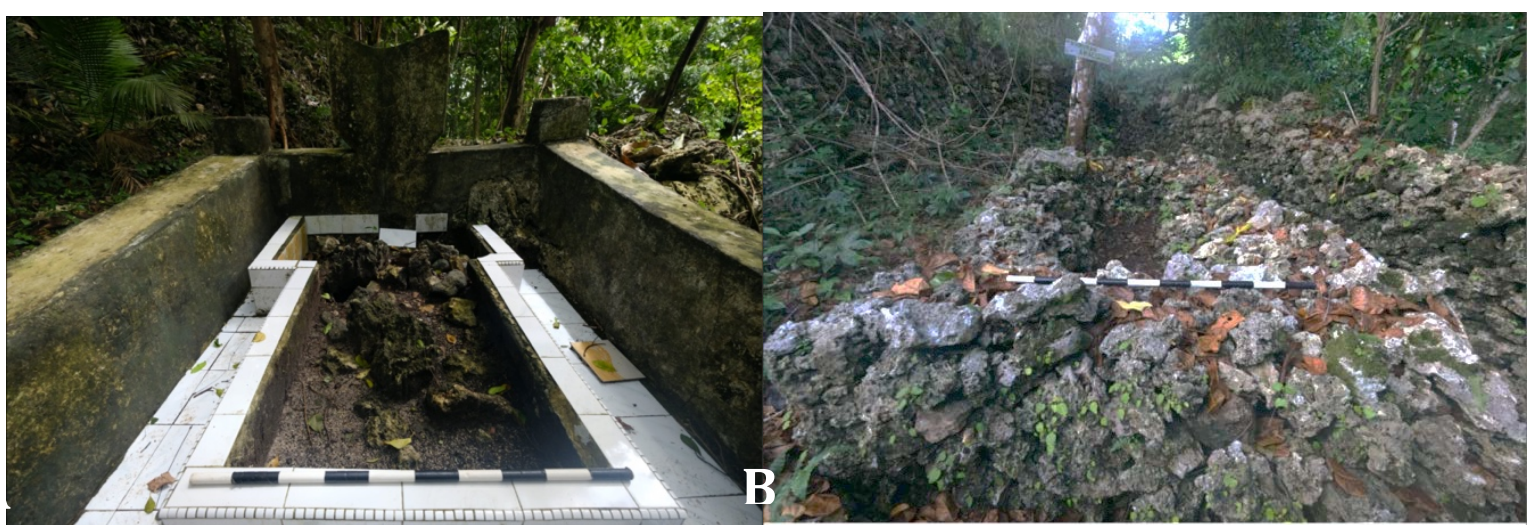

Fig. 22 Ancient tombs (called moori) where rituals are held at Suo Suo Fort (A) and Lagole Fort (B). Source: Regional Agency for Archaeological Research in South Sulawesi Province, 2019.

Locals around Patua Fort on Tomia Island (see Figure 21) believe that their prayers for success in efforts, career, and matchmaking, for safety during voyages and journeys, and for recovery from illness will be granted if they are made at Patua Fort (Taalami 2016: 128). Similarly, another moori tomb, at Suo-suo Fort on Tomia Island (see Figure 22A), is always visited when the Hajj Season comes around as the Hajj pilgrims visit the sacred tomb of Ince Sulaiman to pray for safety on their journey before leaving for Mecca ${ }^{11}$. This ritual is influenced by the lore of the late Ince Sulaiman who converted the people of Tomia to Islam. Unlike the visitors to other sacred places of Wakatobi, those who wish to come to the tomb of Ince Sulaiman are required to be purified (berwudhu) (Taalami 2016: 142). This is also the case for the visitors to the tomb (moori) at Lagole Fort (see Figure $22 \mathrm{~B}$ ), which is believed to the tomb of the propagator of Islam in Tomia.

\footnotetext{
${ }^{10}$ Pers. Comm: La Safriadi, 15 April 2019.

11 Pers. Comm: Ferdiang Agung, 25 April 2019.
} 


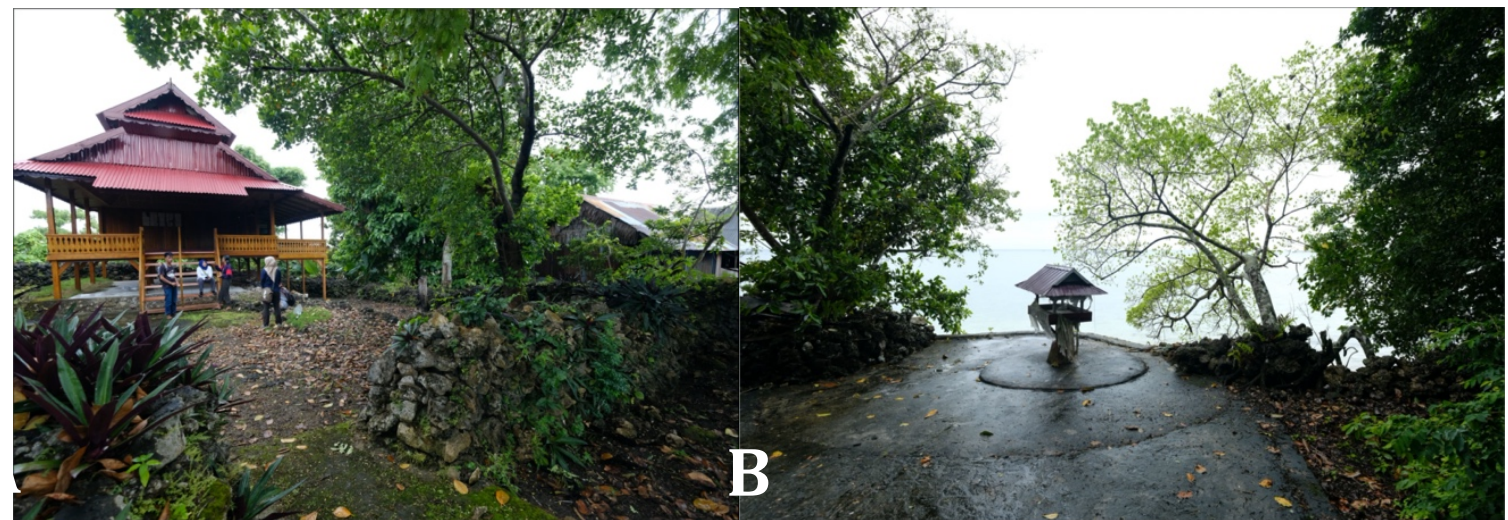

Fig. 23 Kamali Fort (A), the place for the sacred dance of Lariangi at Palea Fort, and La Donda (B), a sacred place for rituals performed by the people of Kaledupa Island. Source: Regional Agency for Archaeological Research in South Sulawesi Province, 2019.

The fort used as the place to perform the Lariangi dance is Palea Fort on Kaledupa Island. The fort has a sacred place named the sacred hall located in the tomb complex (see Figure 23A). The Lariangi dance, a sacred dance inherited by the Kaledupa community from the Buton Sultanate, contains ritual offerings for the Sultanate elders. It also has songs in multiple languages, including Makassar, Wolio and Mbeda-beda ${ }^{12}$. The sacred hall where the dance is performed is seen as a place that symbolizes power and protection for every believer who prays. The hall is also the place for Palea community members to pray before they go on a journey (to seek out a new, proper place to live or to get advanced education); also, whenever a soldier is sent out for duty elsewhere, they send a prayer for success and safety whilst on duty. It is also the place to come to pray to wish for marriage matching or when a Palea community member or the whole community has illness or a plague which is hard to cure (Taalami 2016: 104). Besides the sacred hall of Palea Fort, there is also the very sacred place for the Kaledupa locals called La Donda (see Figure 23B), located near the beach line of Kasuari Village. Rituals performed here are related to cures or when local farms are infested by pests. There is also a ritual performed by floating offerings out to sea using a boat or miniature ship. The ritual is conducted by pande (shaman in the local language) as generations of pande have inherited Wolio language rituals ${ }^{13}$.

\section{Conclusions}

Wakatobians have a strongly insular profile visible from archaeological, historical and local traditions aspects. This profile of the islanders has been formed for hundreds of years and put some colors on the contemporary historiography of Wakatobi and its inhabitants.

The archaeological perspective for the profile is shown by the distribution of archaeological remains in Wakatobi Islands. One line of these remains has been found in the widespread traditional forts, which reflect local settlement by the communities that inhabit these Islands. The traces reveal a defence functionality which shows that there were threats for the inhabitants from outside. One of the threats was related to the location of Wakatobi Islands along the historical Spice Route, which gives us an understanding why this area was contested around the $16^{\text {th }}$ century by the two huge powers at the time, Makassar and Ternate. Besides that, the activity of pirates was intense which

\footnotetext{
12 Pers. Comm: Wa Ode Anihi, 27 April 2019.

${ }^{13}$ Pers. Comm: La Anisi, 27 April 2019.
} 
also posed a threat to the local inhabitants' existence. Conflicts between local communities also contributed a share to the importance of the defence function for the Wakatobi Island settlements. Therefore, it can be stated that the traditional forts were a response of the inhabitants to the security situation within Wakatobi Islands. The overall distribution of the traditional forts shows us the archaeological characteristic of the Islands. Meanwhile, result of the preliminary identification of the ceramic show that they date at least the $15^{\text {th }}$ century, which is correlated with the collected ethno-historical data.

The historical perspective on Wakatobi Islands depicts the formation of the inhabitants' communities. The historical record, captured within local oral traditions, indicates that the people of the Islands came from various origins and places. Of relevance here, the tomb of Ince Sulaiman, believed to be located in Suo-suo Fort (Tomia Island), reflects the presence of a Malay community. The historical record also describes the maritime tradition, especially the Wakatobi people's tradition of working and wandering overseas. One example is that the diaspora of the Wakatobi people in Banda, Maluku, in the $17^{\text {th }}$ century is related to the historical presence of newcomers "Wasuru Baende" in Wakatobi in the $15^{\text {th }}$ century. This historical record correlates with an archaeological finding. One of the tombs in Mandati Tonga Fort (Wangi-wangi Island) is the tomb of Wasuru Baende. Similarly, the diaspora of Wakatobi people in Seram and Ambon in Maluku is explained by Susanto Zuhdi (2014) as the followers of Tulukabesi homecoming to their homeland. The tomb of Patipelong in Suo-suo Fort and the tomb of Kapitan Waloindi believed to be located on Binongko Island. Both tombs mark the existence of the followers of Tulukabesi who settled in Wakatobi Islands. The connection of the Wakatobi people with the archaeological remains can be seen further in their belief system, which is reflected in the maritime rituals that they perform at the traditional forts and other sacred places.

Therefore, it can be said that, seen from the archaeological, historical and maritime tradition perspectives, Wakatobi Islands give us an insight into the maritime traditions of Southeast Asia which have been inter-connected since hundreds of years ago. The Wakatobi people were formed by various outside communities leading to the comprehension that Wakatobi Islands became a knot for the communities who came to this place from different cultural and traditional backgrounds. Meanwhile, on the topic of cultural identity, each fort reflects the united effort of the Wakatobi people in dealing with mutual threats, even though on the other hand each fort reflects the identity of the local community.

\section{Acknowledgment}

The preliminary draft of the article is a part of the Report on the Archaeological Research on "Traditional Forts in Wakatobi Islands: Tracing Their Cultural Characters and Maritime Networks", which was funded by the National Centre for Archaeological Research and conducted based on the Decree Number 1888/H5/P6/2019. We would like to thank all the parties involved in the research, namely the alumni/students of the Archaeology Department of Halu Oleo University, Ersa Dwi Riyanto, S.Sos., M. Sabri, S.Sos., Asma Auliyah, and Andi Adriansyah, and all the research informants. All the illustrations (pictures, floor plans, and maps) were prepared by M. Sabri, S.Sos. We also would like to thank M. Irfan Mahmud, M.Si., who provided suggestions and joined our discussions during the conduct of the research in Wakatobi Islands. Our special gratitude goes to Dr. Horst H. Liebner, who helped us with the sources written in Dutch used in the article. 


\section{References}

Abubakar, LO (1999) Menyambung Kembali Hubungan Leluhur Ambon dengan Buton yang terputus [Reconnecting the broken Relationship between Ambon's Ancestors and Buton]. In: Majalah Budaya Buton (Wolio Molagi) [Buton Culture Magazine (Sustainable Wolio)], 2nd Ed. Kendari: Yayasan Wolio Molagi, 23-43.

Andaya, LY (1991) Local Trade Networks in Maluku in the 16th, 17th, and 18th Centuries. Cakalele, 2(2): 71-96.

Andaya, LY (1993) The World of Maluku: Eastern Indonesia in the Early Modern Period. Honolulu: University of Hawaii Press.

Beck, W and Somerville, M (2005) Conversations Between Disciplines: Historical Archaeology and Oral History at Yarrawarra. World Archaeology, 37(3): 468-483.

Bulbeck, D (1992) A Tale of Two Kingdoms, Historical Archaeology of Gowa and Tallo, South Sulawesi, Indonesia. PhD thesis, The Australian National University, Canberra.

Bulbeck, D and Caldwell, I (2020) The indigenous fortifications of South Sulawesi, Indonesia, and their sociopolitical foundations. In: S O’Connor, A McWilliam \& S Brockwell (eds.) Forts and Fortification in Wallacea: Archaeological and Ethnohistoric Investigations. Canberra: ANU Press, 153-186.

Cortesão, A (ed.) (1944) The Suma oriental of Tomé Pires: an account of the East from the Red Sea to Japan, written in Malacca and India in 1512-1515; and, The Book of Francisco

Rodrigues, rutter of a voyage in the Red Sea, nautical rules, almanack and maps written and drawn in the East before 1515 / translated from the Portuguese MS in the Bibliotheque de la Chambre des Deputes, Paris and edited by Armando Cortesao. London: The Hakluyt Society.

Damm, C (2005) Archaeology, Ethno-history, and Oral Traditions: Approaches to the Indigenous Past. Norwegian Archaeological Review, 38(2): 73-87.

De Graaf, HJ (1977) De geschiedenis van Ambon en de Zuid-Molukken [The history of Ambon and the South Moluccas]. Franeker: Wever.

Dix Grimes, B (2006) Mapping Buru: The Politics of Territory and Settlement on an Eastern Indonesian Island. In: T Reuter \& A Reuter (eds.) Sharing the Earth, Dividing the Land: Land and territory in the Austronesian world. Canberra: ANU Press, 135-155.

Flexner, JL, Willie, E, Lorey, AZ, Alderson, H, Williams, R and Ieru, S (2015) Iarisi's Domain: Historical Archaeology of a Melanesian Village, Tanna Island, Vanuatu. The Journal of Island and Coastal Archaeology, 11(1): 26-49.

Hadara, A (2006) Dinamika Pelayaran Tradisional Orang Buton Kepulauan Tukang Besi [The Dynamics of the Butonese Traditional Voyage, Tukang Besi Islands]. Paper presented at Konferensi Nasional Sejarah VIII, 14-17 November 2006, Jakarta.

Hadara, A (2015) Sejarah Wakatobi dari Praintegrasi hingga Kabupaten [History of Wakatobi from Pre-Integration to District]. Kendari: Himpunan Sarjana Pendidikan Ilmu-Ilmu Sosial Indonesia-Sulawesi Tenggara.

Hall, KR (2011) A History of Early Southeast Asia: Maritime Trade and Societal Development, 100-1500. Lanham: Rowman \& Littlefield Publishers.

Hamid, AR (2007) Pelayaran dan Perdagangan Orang Buton di Kepulauan Wakatobi, 1942-1999 [Shipping and Trading of the Butonese in the Wakatobi Islands, 1942-1999]. Makassar: Universitas Hasanuddin.

Hamid, AR (2015) Merangkai Indonesia Lewat Laut: Kisah Pelaut Binongko [Assembling Indonesia by Sea: The Story of the Binongko Sailors]. Masyarakat Indonesia, 41(2): 177190. 
Hamid, AR (2016) Binongko people’s life in Coral Island. Wacana, 17(1): 19-37.

Handoko, W (2016) Situs Pulau Ujir di Kepulauan Aru: Kampung Kuno, Islamisasi dan

Perdagangan [Ujir Sites in the Aru Islands: Ancient Villages, Islamization and Trade].

Kapata Arkeologi, 12(2): 163-174.

Hanna, W and Alwi, D (1983) Kepulauan Banda: Kolonisasi dan Akibatnya di Kepulauan Pala

[Banda Islands: Colonization and Consequences in the Pala Islands]. Yogyakarta: Yayasan

Obor Indonesia - PT. Gramedia.

Hasanuddin (2010a) Bende Wuta (Benteng Tanah) dalam Konteks Sejarah Budaya Mekongga

Sulawesi Tenggara [Bende Wuta (Earth Fortress) in the Context of the Mekongga Cultural

History of Southeast Sulawesi]. WallenaE: Jurnal Arkeologi Sulawesi Selatan \& Tenggara, 12(2): 159-176.

Hasanuddin (2010b) Eksistensi Benteng Wabula sebagai Bentuk Pertahanan Berlapis Kerajaan Buton, Sulawesi Tenggara [The Existence of Wabula Fort as a Layered Defense from the Buton Kingdom, Southeast Sulawesi]. WallenaE: Jurnal Arkeologi Sulawesi Selatan \& Tenggara, 12(1): 21-37.

Hasanuddin (2020) Forts on Buton Island: Centres of settlement, government and security in Southeast Sulawesi. In: S O’Connor, A McWilliam \& S Brockwell (eds.) Forts and Fortification in Wallacea: Archaeological and Ethnohistoric Investigations. Canberra: ANU Press, 187-210.

Kuenen, PH (1933) The formation of the atolls in the Toekang-Besi-group by subsidence. Proceedings of the Section of Sciences, 36(3): 331-336.

Malihu, L (1998) Buton Timur dan Tradisi Maritim: Kajian Sejarah tentang Pelayaran Tradisional 1957-1995 [East Buton and Maritime Traditions: A Historical Study of Traditional Shipping 1957-1995]. Master thesis, Universitas Indonesia, Jakarta.

Leirissa, R (1973) Kebijaksanaan VOC untuk mendapatkan monopoli perdagangan cengkeh di Maluku Tengah antara tahun-tahun 1615 dan 1652 [VOC Policy of Obtaining a Monopoly on the Clove Trade in Central Maluku between 1615 and 1652]. In: Bunga Rampai Sejarah Maluku. Jakarta: Lembaga Penelitian Sejarah Maluku, 84-115.

Ligtvoet, A (1878) Beschrijving en Geschiedenis van Boeton [Description and History of Boeton]. Bijdragen tot de Taal-, Land- en Volkenkunde, 26(1): 1-112.

Loth, VG (1995) Pioneers and Perkeniers: The Banda Islands in the 18th Century. Cakalele, 6: 1335.

Mahmud, MI (2014) Peradaban Masa Sejarah Situs Ereke, Buton Utara, Propinsi Sulawesi Tenggara [Civilizations Historical Period Ereke Site, North Buton, Southeast Sulawesi Province]. Papua: Jurnal Penelitian Arkeologi Papua dan Papua Barat (Journal of Archaeological Research of Papua and West Papua), 6(1): 69-84.

Mansyur, S (2011) Jejak Tata Niaga Rempah-Rempah dalam Jaringan Perdagangan Masa Kolonial di Maluku [Traces of the Spice Trading System in the Colonial Trading Network in Maluku]. Kapata Arkeologi, 7(13): 20-39.

Mansyur, S (2013) Perdagangan Cengkih Masa Kolonial dan Jejak Penaruhnya di Kepulauan Lease [The Colonial Clove Trade and Its Impact on the Lease Islands]. Kalpataru: Majalah Arkeologi, 22(1): 43-60.

Mansyur, S (2014a) Jejak VOC - Kolonial Belanda di Pulau Buru (Abad 17 - 20 M) [Traces of VOC - Dutch Colonial on Buru Island (17th - 20th Century)]. Amerta: Jurnal Penelitian

Dan Pengembangan Arkeologi, 32(1): 29-34.

Mansyur, S (2014b) Sistem Perbentengan dalam Jaringan Niaga Cengkih Masa Kolonial di Maluku [The Fortification System in the Clove Trading Network during the Colonial Period in Maluku]. Kapata Arkeologi, 10(2): 85-98. 
Mansyur, S (2016) Pengaruh Megalitik di Situs-Situs Pertahanan Tradisional Masa Kolonial Awal di Maluku [Megalithic Influence on Traditional Defence Sites in the Early Colonial Period in Maluku]. Berkala Arkeologi, 36(2): 173-194.

Marzuki, IW (2020) Benteng-Benteng Pertahanan di Gorontalo: Bentuk, Fungsi, dan Perannya [Defense Forts in Gorontalo: Form, Function, and Role]. Purbawidya: Jurnal Penelitian Dan Pengembangan Arkeologi, 9(1): 47-62.

Mundardjito (2010) Nusantara Forts. Inventory and Identification Forts in Indonesia. Jakarta: Pusat Dokumentasi Arsitektur, Direktorat Peninggalan Purbakala Kementerian Kebudayaan dan Pariwisata dan PAC Architect and Consultants, 26-31.

O’Connor, S, McWilliam, A and Brockwell, S (eds.) (2020) Forts and Fortification in Wallacea: Archaeological and Ethnohistoric Investigation. Canberra: ANU Press.

Pigafetta, A (1524) First Voyage Around the World, trans. A Robertson. Manila: Filipiniana Book Guide, 1969

Reid, A (2011) Asia Tenggara dalam Kurun Niaga 1450-1680 Jilid 2 [Southeast Asia in the Age of Commerce 1450-1680 Volume 2]. Jakarta: Yayasan Pustaka Obor Indonesia.

Ricklefs, MC (2001) A History of Modern Indonesia Since c. 1200, 3rd Ed. Stanford, CA: Stanford University Press.

Rinandi, N and Suryaningsih, F (2015) Inventory of Forts in Indonesia. ISPRS Annals of the Photogrammetry, Remote Sensing and Spatial Information Sciences, 2(5): 263-270.

Rosmawati (2018) The Roles of the Liya and Kaledupa Forts at Wakatobi As Defensive Forts of the Buton Kingdom. In: MRA Wahab, RMA Zakaria, M Hadrawi \& Z Ramli (eds.) Selected Topics on Archaeology, History and Culture in the Malay World. Singapore: Springer Nature, 55-72.

Rumphius, GE (1910) De Ambonsche historie, behelsende een kort verhaal der gedenkwaardigste geschiedenissen zo in vreede als oorlog voorgevallen sedert dat de Nederlandsche Oost Indische Comp. het besit in Amboina gehadt heeft [The Ambon History: Containing a Short Story of the Most Memorable Histories, as Peaceful as War has Taken Place Since the Dutch East Indies Com. had the Besit in Amboina]. Bijdragen tot de Taal, Land en Volkenkunde, 64(1/2): 1-327.

Sarjiyanto (1999) Eksistensi Kerajaan Buton: Kajian Benteng-Benteng Masa Kesultanan [The Existence of Buton Kingdom: A Study of Forts During the Sultanate]. WallenaE: Jurnal Arkeologi Sulawesi Selatan \& Tenggara, 2(1): 97-106.

Schapper, A (2019) Build the wall! Village fortification, its timing and triggers in southern Maluku, Indonesia. Indonesia and the Malay World, 47(138): 220-251.

Somba, N (2020) Forts of the Wakatobi Islands in Southeast Sulawesi. In: S O'Connor, A McWilliam \& S Brockwell (eds.) Forts and Fortification in Wallacea: Archaeological and Ethnohistoric Investigations. Canberra: ANU Press, 211-219.

Suryadi, S (2009) Surat Tertua Kerajaan Buton di Negeri Belanda [The Oldest Letter of Buton's Kingdom in the Netherlands]. In: MY Darmawan (ed.) Naskah Buton, Naskah Dunia [Buton Manuscript, World Manuscript]. Bau Bau: Penerbit Respect, 51-62.

Suryadi, S (2018) Melepasi Belenggu Kontrak Kompeni: Refleksi Hubungan Buton-Belanda dalam Warkah Verenigde Oostindische Compagnie kepada Sultan Azimuddin [Releasing the Shackles of the Company Contract: Reflections on Butong-Dutch Relations in the Warkah Verenigde Oostindische Compagnie (VOC) to Sultan Azimuddin]. Malay Literature, 31(2): 227-262. 
Taalami, H (2016) Laporan Akhir Kegiatan Penelitian: Historiografi Benteng-Benteng di Wakatobi [Final Research Report: Historiography of Forts in Wakitobi] [Unpublished work].

Tahara, T, Hamid, AR and Siadi, LOAG (2015) Nilai Budaya Bahari Sabangka Asarope Tradisi Pelayaran Orang Buton Buton [Maritime Cultural Value "Sabangka Asarope” A Butonese Sailing Tradition]. Jakarta: Direktorat Sejarah dan Nilai Budaya, Direktorat Jenderal Kebudayaan, Kementerian Pendidikan dan Kebudayan.

Triwuryani (1995) Alokasi Situs-Situs Arkeologi di Kawasan Das Way Sekampung [Allocation of Archaeological Sites in the River Watershed of Way Sekampung Area]. Seminar Manusia Dalam Ruang: Kajian Kawasan dalam Arkeologi, Yogyakarta 15-16 Maret 1995. Yogyakarta: Pusat Penelitian Arkeologi Nasional dan Balai Arkeologi Yogyakarta.

Zuhdi, S (2010) Sejarah Buton yang terabaikan: Labu Rope Labu Wana [The Neglected History of Buton: Labu Rope Labu Wana]. Yayasan Kebudayaan Masyarakat Buton, Rajawali Pers.

Zuhdi, S (2014) Nasionalisme, Laut, dan Sejarah [Nationalism, the Sea, and History]. Yogyakarta: Komunitas Bambu.

Zuhdi, S (2018) Shipping Routes and Spice Trade in Southeast Sulawesi in the 17th and 18th Century. Journal of Maritime Studies and National Integration, 2(1): 31-44. 